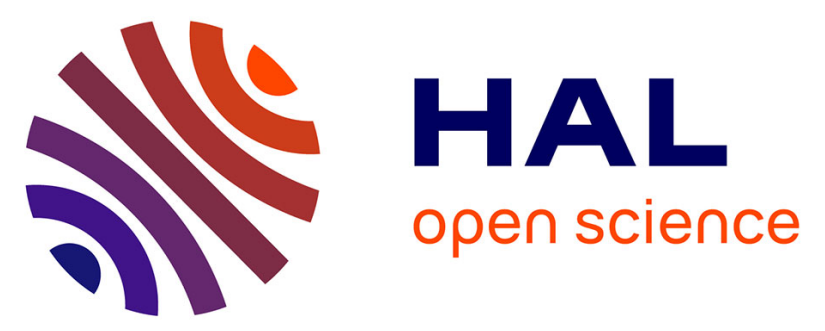

\title{
TUMOR SUPPRESSOR GENE TP53 MUTATIONS IN ATYPICAL VASCULAR LESIONS OF THE BREAST SKIN FOLLOWING RADIOTHERAPY
}

Raffaella Santi, Valentina Cetica, Alessandro Franchi, Monica Pepi, Anna Maria Cesinaro, Clelia Miracco, Milena Paglierani, Vincenzo de Giorgi, Chiara Delfino, Elisa Margherita Difonzo, et al.

\section{To cite this version:}

Raffaella Santi, Valentina Cetica, Alessandro Franchi, Monica Pepi, Anna Maria Cesinaro, et al.. TUMOR SUPPRESSOR GENE TP53 MUTATIONS IN ATYPICAL VASCULAR LESIONS OF THE BREAST SKIN FOLLOWING RADIOTHERAPY. Histopathology, 2011, 58 (3), pp.455. 10.1111/j.1365-2559.2011.03770.x . hal-00614746

\author{
HAL Id: hal-00614746 \\ https://hal.science/hal-00614746
}

Submitted on 16 Aug 2011

HAL is a multi-disciplinary open access archive for the deposit and dissemination of scientific research documents, whether they are published or not. The documents may come from teaching and research institutions in France or abroad, or from public or private research centers.
L'archive ouverte pluridisciplinaire HAL, est destinée au dépôt et à la diffusion de documents scientifiques de niveau recherche, publiés ou non, émanant des établissements d'enseignement et de recherche français ou étrangers, des laboratoires publics ou privés. 


\section{Histopathology}

\section{TUMOR SUPPRESSOR GENE TP53 MUTATIONS IN ATYPICAL VASCULAR LESIONS OF THE BREAST SKIN FOLLOWING RADIOTHERAPY}

\begin{tabular}{|c|c|}
\hline Journal: & Histopathology \\
\hline Manuscript ID: & HISTOP-01-10-0061.R1 \\
\hline Manuscript Type: & Original Article \\
\hline $\begin{array}{r}\text { Date Submitted by the } \\
\text { Author: }\end{array}$ & 15-Apr-2010 \\
\hline Complete List of Authors: & $\begin{array}{l}\text { Santi, Raffaella; University of Florence, Division of Pathological } \\
\text { Anatomy, Department of Critical Care Medicine and Surgery } \\
\text { Cetica, Valentina; University of Florence, Onco-Hematology Unit, } \\
\text { Department of Pediatrics } \\
\text { Franchi, Alessandro; University of Florence, Division of Pathological } \\
\text { Anatomy, Department of Critical Care Medicine and Surgery } \\
\text { Pepi, Monica; University of Florence, Division of Pathological } \\
\text { Anatomy, Department of Critical Care Medicine and Surgery } \\
\text { cesinaro, anna; University of Modena and Reggio Emilia, Anatomic } \\
\text { Pathology } \\
\text { Miracco, Clelia; University of Siena, Anatomic Pathology Section, } \\
\text { Department of Human Pathology and Oncology } \\
\text { Paglierani, Milena; University of Florence, Division of Pathological } \\
\text { Anatomy, Department of Critical Care Medicine and Surgery } \\
\text { De Giorgi, Vincenzo; University of Florence, Department of } \\
\text { Dermatological Sciences } \\
\text { Delfino, Chiara; University of Florence, Department of } \\
\text { Dermatological Sciences } \\
\text { Difonzo, Elisa; University of Florence, Department of Dermatological } \\
\text { Sciences } \\
\text { Pimpinelli, Nicola; University of Florence, Department of } \\
\text { Dermatological Sciences } \\
\text { Bianchi, Simonetta; University of Florence, Division of Pathological } \\
\text { Anatomy, Department of Critical Care Medicine and Surgery } \\
\text { Sardi, Iacopo; University of Florence, Onco-Hematology Unit, } \\
\text { Department of Pediatrics } \\
\text { Santucci, Marco; University of Florence, Division of Pathological } \\
\text { Anatomy, Department of Critical Care Medicine and Surgery } \\
\text { Massi, Daniela; University of Florence, Division of Pathological } \\
\text { Anatomy, Department of Critical Care Medicine and Surgery }\end{array}$ \\
\hline Keywords: & Atypical vascular lesions, Angiosarcoma, Radiation therapy, TP53, \\
\hline
\end{tabular}




\section{S) Scholarone}


Raffaella Santi ${ }^{1}$, Valentina Cetica ${ }^{2}$, Alessandro Franchi ${ }^{1}$, Monica Pepi ${ }^{1}$,

Anna Maria Cesinaro ${ }^{3}$, Clelia Miracco ${ }^{4}$, Milena Paglierani ${ }^{1}$, Vincenzo De Giorgi ${ }^{5}$,

Chiara Delfino ${ }^{5}$, Elisa Margherita Difonzo ${ }^{5}$, Nicola Pimpinelli ${ }^{5}$, Simonetta Bianchi ${ }^{1}$, Iacopo Sardi ${ }^{2}$, Marco Santucci ${ }^{1}$, Daniela Massi ${ }^{1}$

${ }^{1}$ Division of Pathological Anatomy, Department of Critical Care Medicine and Surgery, University of Florence; ${ }^{2}$ Onco-Haematology Unit, Department of Paediatrics, University of Florence; ${ }^{3}$ Department of Pathology, University of Modena and Reggio Emilia; ${ }^{4}$ Department of Human Pathology and Oncology, Anatomical Pathology Section, University of Siena, ${ }^{5}$ Department of Dermatological Sciences, University of Florence; Italy

\section{ADDRESS FOR REPRINTS:}

Raffaella Santi, M.D.

Division of Pathological Anatomy, Department of Critical Care Medicine and Surgery

University of Florence

Viale G.B. Morgagni 85

I-50134 Florence, Italy

Phone: $+39-055-4478138$ 
FAX: $+39-055-4379868$

E-mail: raffaella.santi@yahoo.it

RUNNING TITLE: TP53 in post-radiation vascular lesions

Formatted: No underline, Font color: Auto

KEY WORDS: Atypical vascular lesions, angiosarcoma, radiation therapy, TP53;

Formatted: No underline, Font color: Auto breast skin

Formatted: No underline, Font color: Auto 


\section{ABSTRACT}

Atypical vascular lesions (AVL) occurring at the site of radiotherapy represent

Formatted: No underline, Font color: Auto

an uncommon but well-documented complication in the setting of breast-conserving therapy for breast carcinoma. Although the biological behaviour of AVL has been regarded as benign, it has been suggested that $A V L$ may represent a precursor of angiosarcoma. A better understanding of the biology of $A V L$ is essential in order to assess appropriate patient management.

The purpose of the present study was to investigate alterations of tumour suppressor gene TP53 in a series of radiation-induced AVL and angiosarcomas (AS).

Direct sequencing analysis of the TP53 gene showed the presence of at least one variation in 10 of $12(83.3 \%) \mathrm{AVL}$ and in 7 of $8(87.5 \%) \mathrm{AS}$. The most common alteration in both categories was the P72R polymorphism in exon 4. One angiosarcoma sample carried a pathogenetically relevant disruptive mutation c.592delG, a frameshift deletion in exon 6 , causing a premature stop codon.

The presence of TP53 alterations suggests that its mutational inactivation may Formatted: No underline, Font color: Auto be implicated in the pathogenesis of radiation-associated vascular proliferations. The common mutational pathway suggested by our data supports the hypothesis that $A V L$ and $A S$ are biologically related entities, most likely representing the edges of a morphological continuum. 


\section{INTRODUCTION}

Atypical vascular lesions (AVL) of the skin are a well-known complication

Formatted: No underline, Font color: Auto

Deleted:

occurring after radiation in the setting of breast-conserving therapy for breast

carcinoma. Originally described by Fineberg and Rosen in $1994^{1}$, these lesions are

characterised by an anastomosing pattern of vascular channels lined by

hyperchromatic endothelial cells and occasional dissection of dermal collagen, as

Formatted: No underline, Font

color: Auto observed in well-differentiated angiosarcomas (AS) ${ }^{1}$.

Despite morphological overlap with AS, the clinical behaviour of AVL was

Formatted: No underline, Font color: Auto

Deleted: vior

initially considered benign, as these lesions did not appear to represent a risk factor

for the development of angiosarcoma, being able neither to recur nor to develop

Deleted: neither

metastasis, and being safely cured by local excision ${ }^{1,2}$. In subsequent years,

Deleted: $e$

however, the indolent nature of $\mathrm{AVL}$ has been questioned $\mathrm{d}_{2}$ given that areas

histologically indistinguishable from $A V L$ were observed within $A S^{3,4,5}$. In addition,

patients with AVL who later developed AS have been occasionally reported ${ }^{6,3,5}$,

raising the possibility that in some cases AVL may indeed represent a morphological

precursor of AS. Recent studies have also emphasised the difficult histological

Deleted: $z$

interpretation of some cases due to inadequate tissue biopsies or sampling bias ${ }^{4}$. It

has, therefore, been recommended that patients diagnosed with AVL undergo

complete excision with careful specimen sampling and close follow up ${ }^{7}$.

Little is known concerning the pathogenesis of $A V L$ on irradiated skin. Some

Formatted: No underline, Font color: Auto authors believe that AVL result from permanent dilatation of lymphatic capillaries associated with disruption of the flow of lymphatic fluid ${ }^{8}$, while others consider them to be a reactive proliferation secondary to vascular damage due to both surgery and radiation $^{1,2,9}$. Knowledge of the genetic changes, including TP53 gene alterations, of the wide spectrum of radiation-induced vascular proliferations of breast skin, may be 
helpful in clarifying the pathogenesis, the biological significance (reactive vs.

neoplastic process) of $A V L_{z}$ and their relationship with $A S$.

Radiation causes DNA double-strand breaks, which may result in deletions and rearrangements and changes in gene expression. A potential target for ionisjing radiation is the tumour suppressor gene $T P 53$, the most frequently mutated gene in a wide variety of human cancers. TP53 deficient mice developed spontaneous AS, suggesting that the loss of p53 function plays a significant role in tumorigenesis of $\mathrm{AS}^{10}$. Little information exists on $T P 53$ gene mutation in human liver and cutaneous $\mathrm{AS}^{11,12,13}$. The frequency of TP53 mutations in AS differs by site, which might be due to different aetiologies ${ }^{13}$. Patients with angiosarcoma who had received radiotherapy for cavernous haemangioma or malignant lymphoma revealed TP53 mutations, one of which was localised to a dipyrimidine site $^{13}$. Although the exact role of TP53 gene abnormalities in human AS tumorigenesis remains unclear, it has been underlined that a mutated form of the TP53 gene induces the expression of mRNA encoding vascular endothelial growth factor $(\mathrm{VEGF})^{14}$, a specific mitogen for endothelial cells in vitro and angiogenic factor in vivo ${ }^{15}$. Thus, TP53 gene alterations, inducing overexpression of VEGF, may be involved in the development of AS, at least in some cases. VEGF and its receptor ( $f / t)$ mRNA have been found to be co-expressed in tumour cells of angiosarcoma, suggesting some paracrine or autocrine control mechanisms of proliferation ${ }^{16}$.

The purpose of the present study was to investigate the presence of p53 alterations at the level of either protein expression or gene mutations in a series of AVL in comparison with post-radiation cutaneous AS, with the two-fold aim of verifying whether p53 is implicated in the pathogenesis of radiation-induced vascular
Deleted:

Formatted: No underline, Font color: Auto

Deleted:

Deleted: $z$

Formatted: Font: $12 \mathrm{pt}$, Not Italic, Font color: Auto

Formatted: Font: $12 \mathrm{pt}$, Font color: Auto

Formatted: Font: 12 pt, Not Italic, Font color: Auto

Formatted: Font: $12 \mathrm{pt}$, Font color: Auto

Formatted: Font: $12 \mathrm{pt}$, Not Italic, Font color: Auto

Formatted: Font: $12 \mathrm{pt}$, Font color: Auto

Formatted: Font: 12 pt, Not Italic, Font color: Auto

Formatted: Font: 12 pt, Font color: Auto

Formatted: Font: 12 pt, Not Italic, Font color: Auto

Formatted: Font: 12 pt, Not Italic

Formatted: Font: 12 pt, Not Italic, Font color: Auto

Formatted: Font: $12 \mathrm{pt}$, Font color: Auto

Formatted: Font: 12 pt, Not Italic, Font color: Auto

Formatted: Font: 12 pt, Font color: Auto

Formatted: Font: 12 pt, Not Italic, Font color: Auto

Formatted: Font: 12 pt, Font color: Auto

Formatted: Font: 12 pt, Not Italic,

Font color: Auto

Formatted: Font: 12 pt, Font color: Auto

Formatted: Font: 12 pt, Not Italic, Font color: Auto

Formatted: Font: $12 \mathrm{pt}$, Font color: Auto

Formatted: Font: 12 pt, Not Italic, Font color: Auto

Formatted: Font: $12 \mathrm{pt}$, Font color: Auto

Formatted: Font: 12 pt, Not Italic, Font color: Auto

Formatted: Font: 12 pt, Not Italic,

Font color: Auto 
proliferations and of collecting evidence in support of a molecular link between AVL and AS.

\section{MATERIALS AND METHODS}

Selection of cases

Twenty patients classified as either radiation-associated cutaneous AVL (12 cases)

or AS (8 cases), were identified from the files of the Division of Pathological Anatomy,

Department of Critical Care Medicine and Surgery, University of Florence, Italy; the

Department of Pathology and Oncology, University of Siena, Italy; and the

Department of Pathology, University of Modena and Reggio Emilia, Modena, Italy.

We employed the criteria of Fineberg and Rosen in distinguishing AVL from $\mathrm{AS}^{1}$.

Clinical data were obtained from Jaboratory request forms, pathology reports, or

referring dermatologists. The following data were recorded, when available, for each

Deleted: if

patient: age, sex, primary disease, time latency interval elapsed between

radiotherapy and diagnosis of vascular lesion, clinical appearance, location and

follow-up.

\section{Immunohistochemistry}

Immunohistochemical studies were performed both in AVL and in AS using the

monoclonal antibody mouse anti-human p53 (clone DO-7, Ventana Medical Systems,

Inc.Tucson, AZ; prediluted). Immunohistochemistry was performed on paraffin sections (5- $\mu \mathrm{m}$ thickness) of formalin-fixed tissues, using a Ventana BenchMark® XT automated staining system (Ventana Medical Systems). The sections were treated with an antigen-retrieval procedure for 30 minutes in Cell Conditioning Solution 1 
(CC1). Endogenous biotin was blocked with the relevant kit. Tissue sections were incubated with the anti-human p53 antibody for 32 minutes at $37^{\circ} \mathrm{C}$ in BenchMark $\circledast$ XT autostainer and revealed with the iVIEW DAB detection kit, yielding a brown reaction product. After the staining run was complete, the slides were removed from the autostainer, the sections lightly counterstained with Mayer's haematoxylin, dehydrated, and mounted with permanent mounting medium. As negative control, the primary antibody was substituted with a Ventana dispenser, filled with a non-immune mouse serum at the same concentration.

\section{Microdissection}

One paraffin block was selected to represent the tumour from each patient. Six

to ten serial sections ( $4 \mu \mathrm{m}$ thickness) were obtained from the paraffin-embedded tissue blocks. The first and last sections were stained with haematoxylin and eosin to confirm that the intervening blank slides contained the lesional material. Tissue fragments were microdissected using stereomicroscopic visualisation from blank, deparaffinised slides. Areas that contained large amounts of blood, necrosis, or

Deleted: $z$ contaminating normal tissue were avoided in microdissection. Post-microdissected slides were evaluated to confirm accurate sample microdissection.

\section{TP53 mutation analysis}

TP53 mutation analysis was performed in $12 \mathrm{AVL}$ and $8 \mathrm{AS}$. DNA was extracted from microdissected paraffin-embedded tissues, using a manual protocol ${ }^{17}$. PCR primers for exons 4-9, encoding the DNA binding domain of TP53 gene, were designed to obtain fragments of no more than $300 \mathrm{bp}$. Amplification reactions were performed with $60 \mathrm{ng}$ of DNA, $10 \mathrm{ng}$ of each primer, $200 \mu \mathrm{M}$ dNTPs, 1x PCR reaction

Formatted: Font: $12 \mathrm{pt}$, Font color: Auto

Formatted: Font: $12 \mathrm{pt}$, Font color: Auto

Formatted: Font: 12 pt, Not Italic, Font color: Auto

Deleted:

Formatted: Font: 12 pt, Font color: Auto

Formatted: Font: 12 pt, Not Italic,

Font color: Auto 
buffer, and $2.5 \mathrm{U}$ Taq polymerase in a final volume of $25 \mu$ l. PCR products were directly sequenced on both strands using an ABI PRISM 3130XL Genetic Analyzer (Perkin-Elmer Applied Biosystems, Foster City, CA).

In silico analysis

Unknown mutations were tested by bioinformatics, We used two dedicated softwares: SIFT (Sorting Intolerant From Tolerant:

http://blocks.fhcrc.org/sift/SIFT.html) and POLYPHEN (prediction of functional effect of human nsSNPs: http://genetics.bwh.harvard.edu/pph/).

Formatted: Font: $12 \mathrm{pt}$, Font color: Auto

Formatted: Font: $12 \mathrm{pt}$, Not Italic, Font color: Auto

Deleted: facilities

Formatted: No underline, Font color: Auto

Formatted: No underline, Font color: Auto

\section{RESULTS}

Clinical findings

Clinical data are summarised in Table 1. Patients with AVL were all female, color: Auto

Formatted: No underline, Font color: Auto

Formatted: No underline, Font color: Auto

Deleted: $z$ ranging from 47 to 69 years of age. Eleven patients underwent conservative surgery for breast carcinoma. In an additional case, a radical bilateral mastectomy was performed for metachronous bilateral breast carcinoma. All patients received postoperative external radiotherapy with doses varying from 44 to 60 Gy. Lesions were clinically described as solitary or multiple erythematous, skin-coloured or transparent papules, vesicles or discrete nodules/plaques, appearing within the prior irradiation field with a latency interval from 19 to 192 months after radiotherapy (mean 80.7, median 73). No oedema or ecchymoses were described. Other skin lesions at the site of radiotherapy have not been detected. In ten cases, lesions were completely removed by local excision, whereas in two cases an incision biopsy was performed. 
Follow-up data were available for all AVL patients. None of the patients with AVL developed an AS or recurrent lesions or metastases, and they all remained well 3 to 146 months after diagnosis (mean 42.6, median 34).

Patients with AS were all female, ranging from 53 to 90 years of age. They all had an antecedent history of radiotherapy following conservative/radical surgery for jpsilateral breast carcinoma. Most of the lesions were described as multiple purpleerythematous plaques or nodules on mammary irradiated skin. One patient had a purple-erythematous ring-shaped patch, whereas in another case AS presented as a diffuse breast oedema (peau d'orange). The latent period between radiation therapy for breast carcinoma and the diagnosis of AS ranged from 72 to 168 months (mean 115.2, median 96) after radiotherapy for the five patients whose anamnestic data were available. Patients were treated with radical mastectomy in four cases; in three patients initial treatment consisted in incomplete excision. Follow-up data were available in 7 patients. Four are alive 12 to 41 months after diagnosis (mean 25.2, median 24). Three patients died of metastatic breast carcinoma from 12 to 16 months after the diagnosis of cutaneous AS.

\section{Histopathological findings}

At low power, AVL appeared as relatively well-circumscribed, wedge-shaped proliferations of markedly dilated irregular vascular spaces located in the dermis (Figures 1, 2). Vascular proliferations often projected the overlying normal epidermis upwards, thus explaining the elevated clinical appearance of the lesion (Figure 3). In other cases, lesions were flat, with a plaque-like morphology. Vascular spaces were lined by a single layer of endothelial cells with plump-oval or flattened nuclei (Figure 4A-B). Endothelial cells occasionally protruded into the lumen in a hobnail pattern
Formatted: No underline, Font color: Auto

Formatted: No underline, Font color: Auto

Formatted: No underline, Font color: Auto

Formatted: No underline, Font color: Auto

Deleted: an

Deleted: omo

Formatted: No underline, Font color: Auto

Formatted: No underline, Font color: Auto

Formatted: No underline, Font color: Auto

Formatted: No underline, Font color: Auto 
(Figure 4C). Numerous small projections of stroma covered by a single layer of endothelium were a constant finding (Figures 4D). The papillae were either attached to the internal surface of the vessels or apparently lying free in the lumen. Other lesions descended into the deep dermis. Vascular spaces became smaller and their lumina more irregular, angulated or slit-like. Dissection of dermal collagen was only focally and rarely encountered. Mitoses were found in one case. Lumina were empty or filled with a small amount of proteinaceous material. Erythrocytes were seen within vascular spaces in a small number of lesions, whereas extravasated red blood cells or "blood lakes" were not observed. The stroma contained a lymphohistiocytic infiltrate with a variable number of plasma cells that varied from mild to dense.

AS were multifocal or diffuse vascular proliferations showing infiltration into the Formatted: No underline, Font color: Auto subcutis. Some cases also showed infiltration into the underlying breast parenchyma. Tumours were all high-grade and were composed of solid aggregates of epithelioid or spindle-cells with slit-like spaces containing intraluminal and extravasated red blood cells. In all cases, tumour cells displayed prominent nuclei, brisk mitotic activity, Deleted: and an infiltrative growth pattern with prominent dissection between dermal collagen bundles. In three AS, areas consistent with AVL were observed at the periphery of the malignant tumour (Figures 5-6).

\section{Immunohistochemical findings}

p53 immunostaining was evaluated in 10/12 AVL, with variable expression and color: Auto heterogeneous distribution within single cases (Table 2, Figure 7). In 4/10 (40\%) cases p53 expression was detected in less than $20 \%$ of positive cells, whereas in another $4 / 10(40 \%)$ cases, p53 was expressed by a variable percentage between 
$20 \%$ and $50 \%$ of cells. In one case $(10 \%)$, no p53 stained cell was detectable,

whereas in another case (10\%), the percentage of stained cells was more than $50 \%$.

p53 protein was expressed in $7 / 8(87.5 \%)$ AS. In four cases (50\%)

Formatted: No underline, Font

color: Auto

immunostaining was less than $20 \%$ of the neoplastic cells. In two cases $(25 \%)$, the

percentage of positive cells was comprised between $20 \%$ and $50 \%$, whereas in one

case $(12.5 \%)$ positive cells constituted more than $50 \%$ of the lesion.

AS with peripheral $A V L_{2}$ resembling areas showed no difference in $\mathrm{p} 53$ protein

Formatted: No underline, Font

color: Auto expression.

\section{TP53 mutation analysis}

Overall, we identified some TP53 variation in 10/12 (83.3\%) AVL and in 7/8

(87.5\%) AS. Detailed results of TP53 mutational analysis are summarised in Table 2.

Formatted: No underline, Font color: Auto

Formatted: No underline, Font color: Auto

Deleted: $z$

Formatted: No underline, Font color: Auto

Deleted: hav

Deleted: been

Deleted: $z$ to be non-damaging (non-disruptive) mutations, except for K319N in exon 9, which was found in 2/12 (16.6\%) AVL and 2/8 (25\%) AS (Table 3).

\section{DISCUSSION}

TP53 mutation analysis has never previously been applied to the evaluation of AVL molecular profiles. In this study, we found TP53 variations in the majority (83\%)

Formatted: No underline, Font color: Auto

Formatted: No underline, Font color: Auto

Formatted: No underline, Font color: Auto 
of $A V L$ and in a similar percentage $(87.5 \%)$ of post-radiation cutaneous AS. The most common variation in both categories was the P72R polymorphism in both AVL and AS, and the F54L variation in exon 4 detected in AVL. Interestingly, in one angiosarcoma sample, but in none of the AVL samples, we found a pathogenetically relevant disruptive mutation c.592delG in exon 6 , a frameshift deletion causing a premature stop codon, resulting in a truncated p53 protein. Although the recognition Formatted: No underline, Font of $A V L$ as a morphological precursor to AS is still a controversial issue, the common mutational pathway suggested by our data provides preliminary results in support of this hypothesis, and also information relevant to the pathogenesis of atypical and malignant vascular proliferations of irradiated breast skin. It is conceivable that the TP53 mutations occur early in the tumorigenesis of these atypical vascular proliferations, and may be responsible in part for the initiation or potentiation of endothelial cell growth. Subsequently, the angiosarcoma lesions could be exposed to additional stimuli, giving rise to the frankly malignant phenotype.

The TP53 proline 72 arginine (P72R) polymorphism was a common mutation harboured in AVL and AS categories. TP53 mutations causing a malfunction of the p53 pathway are frequently encountered in many different types of human cancers ${ }^{19}$. Formatted: No underline, Font color: Auto color: Auto, Not Highlight The core domain of p53 is highly conserved and confers DNA-binding specificity to the protein. Variations at this site make up $98 \%$ of the transforming mutations in p5 $3^{18}$. Conversely, polymorphic sequence variations are expected to have modest or no cancer-related biological effect ${ }^{19}$. The TP53 codon 72 has been extensively studied because it affects the gene coding sequence, generating polymorphic variants with different biochemical and biological activities. The P72R variant has

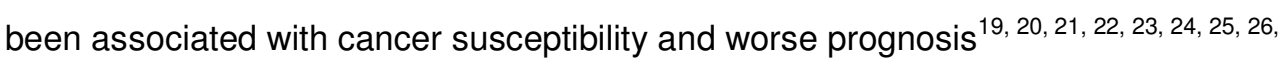
${ }^{27,}{ }^{28}$. In addition, codon 72 polymorphism has been shown to modulate TP53- 
dependent apoptosis, and therefore, modify sensitivity to chemotherapeutic agents ${ }^{29}$. Nevertheless, meta-analyses based on several studies investigating the susceptibility to lung and cervical cancer found no association between TP53 codon 72 polymorphism and cancer risk ${ }^{30,31}$. Methodological issues could have contributed to heterogeneity among previously reported results ${ }^{30,31}$.

In agreement with previous studies, we found that p53 immunohistochemistry

did not always correlate with the mutational status of the TP53 gene ${ }^{32}$. p53

immunohistochemistry in AVL and AS revealed similar staining characteristics in both pattern and quantity. This further supports the biological and molecular similarities between these apparently distinct entities. Nuclear p53 immunostaining was variable in cases harbouring TP53 mutations, suggesting that TP53 mutations may be only one of the factors resulting in an altered p53 signal system.

Very little has been done at the molecular level to increase our understanding Formatted: No underline, Font color: Auto of the genetic alterations involved in malignant transformation of endothelial cells. Transgenic mice that were deficient in $p 53$ demonstrated a relatively high incidence (23\%) of cutaneous AS, suggesting that alterations in the $p 53$ gene may be pathogenetically important ${ }^{10}$. In human tissues, Naka et al ${ }^{13}$ analysed $p 53$ mutations in paraffin-embedded specimens from 33 patients with AS by PCR single-stranded polymorphism, followed by direct sequencing, and found 17 cases with p53 mutations, concluding that $p 53$ mutations are a major pathway for the development of human AS. At the protein level, overexpression of p53 and MDM-2 protein has been found to correlate with the increased VEGF expression that is found in nearly $80 \%$ of $\mathrm{AS}^{33}$. Another study also supported the hypothesis that VEGF and the VEGF receptor system play a role in proliferation and growth of AS by showing that tumour 
cells of the haemangiosarcoma cell line ISO-HAS contain a p53 mutation and express the mRNA of VEGF and its 2 receptors, flt- 1 and $\mathrm{KDR}^{34}$.

AVL described in the current study displayed a fully benign clinical course, in agreement with the vast majority of cases so far described. $\frac{1-5,7-8,35}{A_{-1}-\ldots-1}$

Histopathologically, our cases met the diagnostic criteria proposed by Fineberg and Rosen ${ }^{1}$. In 1999, Diaz-Cascajo et al. first proposed the term "benign lymphangiomatous papules (BLAP)" on the basis of the clinical and histological findings together with the absence of recurrences or distant metastases in their series and in previously reported cases $^{2}$. Requena et al suggested the consideration of BLAP separated from more atypical vascular proliferations resembling benign lymphangioendothelioma (acquired progressive lymphangioma), patch-stage Kaposi's sarcoma, and well-differentiated $\mathrm{AS}^{8}$. In 2008, Patton et $\mathrm{al}^{5}$ reinforced the observation and subclassified AVL in to lymphatic type (LT AVL) and vascular type (VT AVL). LT AVL were described as circumscribed proliferations of ectatic thinwalled vessels confined to the dermis; the vessels were often back to back and showed hobnail endothelial cells that protruded into the lumina ${ }^{5}$. In contrast, VT AVL showed round to linear capillary vessels randomly arranged throughout the dermis, and $40 \%$ of these lesions displayed significant cytological atypia ${ }^{5}$. Interestingly, VT AVLs were considered to have a higher risk of association with AS than with LT $\mathrm{AVL}^{5}$. In our series, 2 cases could be classified as LT AVL, and 3 VT AVL cases displayed a vascular pattern, but in the majority of cases features of both patterns were almost equally represented, in support of the $\mathrm{AVL}$ morphological heterogeneity.

The morphological profile of $A V L$ showing progression to $A S$ is yet to be clearly defined. In previous studies, AVL showing progression to AS were described showing prominent nucleoli, occasional infiltration of the subcutis, mitotic figures, and 
moderate to significant cytological atypia ${ }^{3,4,5}$. As previously emphasised ${ }^{5}$, we agree

that histopathology in the context of post-radiation vascular proliferation of the breast skin should be interpreted with extreme caution, especially when specimens represent only partial sampling of the lesion. Clinical features may be diagnostically helpful since all the patients who experienced an adverse outcome after an initial diagnosis of $A V L$ were older, had a shorter interval from radiations as compared to those who showed no recurrence or progression, and were associated with erythema, induration, inflammatory changes, discolouration and telangiectasias ${ }^{4}$. In any event, these latter morphological observations, coupled with our preliminary findings, suggest an initial common mutational pathway involving p53 alterations, which favours the hypothesis that indeed AVL and AS may represent a morphologic continuum, implying that AVL could, at least in some cases, be the actual precursor of AS or incipient AS. However, the risk of progression to malignancy is likely to be

Deleted: be Deleted: an

Formatted: No underline, Font color: Auto

Formatted: No underline, Font color: Auto 


\section{REFERENCES}

1. Fineberg S, Rosen PP. Cutaneous angiosarcoma and atypical vascular lesions Formatted: No underline, Font of the skin and breast after radiation therapy for breast carcinoma. Am J Clin Pathol 1994;102:757-63.

2. Diaz-Cascajo $\mathrm{C}$, Borghi $\mathrm{S}$, Weyers $\mathrm{W}$, Retzlaff $\mathrm{H}$, Requena L, Metze D. Benign Formatted: No underline, Font color: Auto lymphangiomatous papules of the skin following radiotherapy: a report of five new cases and review of the literature. Histopathology 1999;35:319-27.

3. Brenn T, Fletcher CD. Radiation-associated cutaneous atypical vascular Formatted: No underline, Font color: Auto lesions and angiosarcoma: clinicopathologic analysis of 42 cases. Am J Surg Pathol 2005;29:983-96.

4. Mattoch IW, Robbins JB, Kempson RL, Kohler S. Post-radiotherapy vascular Formatted: No underline, Font color: Auto proliferations in mammary skin: a clinicopathologic study of 11 cases. J Am Acad Dermatol 2007;57:126-33.

5. Patton KT, Deyrup AT, Weiss SW. Atypical vascular lesions after surgery and Formatted: No underline, Font color: Auto radiation of the breast: a clinicopathologic study of 32 cases analyzing histologic heterogeneity and association with angiosarcoma. Am J Surg Pathol 2008;32:943-50. 
6. Di Tommaso L, Fabbri A. Cutaneous angiosarcoma arising after radiotherapy treatment of a breast carcinoma. Description of a case and review of the literature. Pathologica 2003;95:196-202.

7. Uchin JM, Billings SD. Radiotherapy-associated atypical vascular lesions of the Formatted: No underline, Font breast. J Cutan Pathol 2009;36:87-8.

8. Requena L, Kutzner H, Mentzel T, Durán R, Rodríguez-Peralto JL. Benign vascular proliferations in irradiated skin. Am J Surg Pathol 2002;26:328-37.

9. Rosso R, Gianelli U, Carnevali L. Acquired progressive lymphangioma of the Formatted: No underline, Font skin following radiotherapy for breast carcinoma. J Cutan Pathol 1995;22:1647.

10. Donehower LA, Harvey M, Slagle BL, et al. Mice deficient for $\mathrm{p} 53$ are Formatted: No underline, Font color: Auto developmentally normal but susceptible to spontaneous tumours. Nature 1992;356:215-21.

11. Hollstein M, Marion MJ, Lehman T, et al. p53 mutations at A:T base pairs in Formatted: No underline, Font color: Auto angiosarcomas of vinyl chloride-exposed factory workers. Carcinogenesis 1994;15:1-3.

12. Soini Y, Welsh JA, Ishak KG, Bennett WP. p53 mutations in primary hepatic Formatted: No underline, Font color: Auto angiosarcomas not associated with vinyl chloride exposure. Carcinogenesis 1995;16:2879-81. 
13. Naka N, Tomita Y, Nakanishi $\mathrm{H}$, et al. Mutations of p53 tumor-suppressor gene

in angiosarcoma. Int J Cancer 1997;71:952-5.

14. Kieser A, Weich HA, Brandner G, Marmé D, Kolch W. Mutant p53 potentiates Formatted: No underline, Font color: Auto protein kinase $\mathrm{C}$ induction of vascular endothelial growth factor expression. Oncogene 1994;9:963-9.

15. Gospodarowicz D, Abraham JA, Schilling J. Isolation and characterization of a Formatted: No underline, Font color: Auto vascular endothelial cell mitogen produced by pituitary-derived folliculostellate cells. Proc Natl Acad Sci U S A 1989;86:7311-5.

16. Hashimoto $M$, Ohsawa $M$, Ohnishi $A$, et al. Expression of vascular endothelial Formatted: No underline, Font color: Auto growth factor and its receptor mRNA in angiosarcoma. Lab Invest 1995;73:859-63.

17. Coombs NJ, Gough AC, Primrose JN. Optimisation of DNA and RNA extraction Formatted: No underline, Font color: Auto from archival formalin-fixed tissue. Nucleic Acids Res 1999;27:e12.

18. Cho Y, Gorina S, Jeffrey PD, Pavletich NP. Crystal structure of a p53 tumor suppressor-DNA complex: understanding tumorigenic mutations. Science 1994;265:346-55.

19. Whibley C, Pharoah PD, Hollstein M. p53 polymorphism: cancer implications. Nat Rev Cancer. 2009;9:95-107. 
20. Storey A, Thomas M, Kalita A, et al. Role of a p53 polymorphism in the development of human papillomavirus-associated cancer. Nature 1998;393:229-34.

21. Sourvinos G, Rizos E, Spandidos DA. p53 Codon 72 polymorphism is linked to Formatted: No underline, Font color: Auto the development and not the progression of benign and malignant laryngeal tumours. Oral Oncol 2001;37:572-8.

22. Cortezzi SS, Provazzi PJ, Sobrinho JS, et al. Analysis of human papillomavirus prevalence and TP53 polymorphism in head and neck squamous cell

Formatted: Not Highlight

Formatted: No underline, Font color: Auto, Italian (Italy)

Formatted: No underline, Font color: Auto carcinomas. Cancer Genet Cytogenet 2004;150:44-9.

23. Siddique MM, Balram C, Fiszer-Maliszewska L, et al. Evidence for selective Formatted: No underline, Font color: Auto, French (Canada) expression of the p53 codon 72 polymorphism implications in cancer development. Cancer Epidemiol Biomarkers Prev 2005;14:2245-52.

24. Nelson HH, Wilkojmen M, Marsit CJ, Kelsey KT. TP53 mutation, allelism and survival in non-small cell lung cancer. Carcinogenesis 2005;26:1770-3.

25. Bond GL, Levine AJ. A single nucleotide polymorphism in the p53 pathway Formatted: No underline, Font color: Auto interacts with gender, environmental stresses and tumor genetics to influence cancer in humans. Oncogene 2007;26:1317-23. 
26. Marin MC, Jost CA, Brooks LA, et al. A common polymorphism acts as an intragenic modifier of mutant p53 behaviour. Nat Genet 2000;25:47-54.

27. Soulitzis N, Sourvinos G, Dokianakis DN, Spandidos DA. p53 codon 72 polymorphism and its association with bladder cancer. Cancer Lett 2002;179:175-83.

28. Boltze C, Roessner A, Landt O, Szibor R, Peters B, Schneider-Stock R. Homozygous proline at codon 72 of p53 as a potential risk factor favoring the development of undifferentiated thyroid carcinoma. Int J Oncol 2002;21:1151-4.

29. Toyama T, Zhang Z, Nishio M, et al. Association of TP53 codon 72 polymorphism and the outcome of adjuvant therapy in breast cancer patients. Breast Cancer Res 2007;9:R34.

30. Klug SJ, Ressing M, Koenig J, et al. TP53 codon 72 polymorphism and cervical cancer: a pooled analysis of individual data from 49 studies. Lancet Oncol 2009;10:772-84.

31. Matakidou A, Eisen T, Houlston RS. TP53 polymorphisms and lung cancer risk: a systematic review and meta-analysis. Mutagenesis 2003;18:377-85.

32. Taylor D, Koch WM, Zahurak M, Shah K, Sidransky D, Westra WH. Immunohistochemical detection of p53 protein accumulation in head and neck cancer: correlation with p53 gene alterations. Hum Pathol 1999;30:1221-5.
Formatted: No underline, Font color: Auto, French (Canada)

Formatted: No underline, Font color: Auto

Formatted: No underline, Font color: Auto

Formatted: No underline, Font color: Auto

Formatted: No underline, Font color: Auto, French (Canada)

Formatted: No underline, Font color: Auto 
33. Zietz C, Rössle M, Haas C, et al. MDM-2 oncoprotein overexpression, p53

gene mutation, and VEGF up-regulation in angiosarcomas. Am J Pathol

1998;153:1425-33.

34. Amo Y, Masuzawa M, Hamada Y, Katsuoka K. Expression of vascular

Formatted: No underline, Font color: Auto endothelial growth factor in a human hemangiosarcoma cell line (ISO-HAS).

Arch Dermatol Res 2001;293:296-301.

35. Gengler C, Coindre JM, Leroux A, et al. Vascular proliferations of the skin after Formatted: No underline, Fon color: Auto, French (Canada) radiation therapy for breast cancer: clinicopathologic analysis of a series in Formatted: No underline, Font color: Auto favor of a benign process: a study from the French Sarcoma Group. Cancer 2007;109:1584-98. 
TABLE 1

Clin ical features of the 12 atypical vascular lesions and 8 angiosarcomas developed in the

Latency Clinical presentation

Deleted: Omo

\begin{tabular}{|c|c|c|}
\hline Age/ & Primary & Surgery \\
\hline Sex & disease & \\
\hline $67 / F$ & Bilateral BC & Radical, bilateral \\
\hline $64 / F$ & Jps lateral BC & Conservative \\
\hline $47 / F$ & Jps lateral BC & Conservative \\
\hline $69 / F$ & Jps lateral BC & Conservative \\
\hline
\end{tabular}

interval*

(months)

49/F Jpslateral BC Conservative

58

63

$$
\begin{array}{r}
63 / \\
66 /
\end{array}
$$

${ }_{4} 75 \quad$ Erythematous plaque/nodule

CE

Nodular lesion

$$
\text { IB }
$$

$60 \quad$ Erythematous papule

IB

48

Erythematous papule

CE

$$
61
$$

Jps |lateral BC

Conservative

57

Nodular lesion

CE

65/F Jps lateral BC Conservative

72

Erythematous papule

CE$$
47
$$

Jps lateral BC

Conservative

96

$$
56 /
$$

$55 /$

$76 /$

81

$$
81
$$$$
80 /
$$

(a)




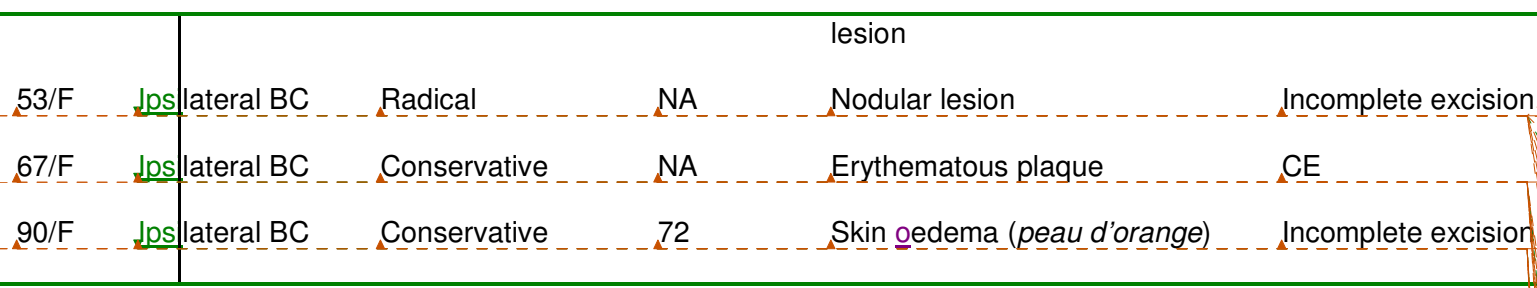

AVL: atypical vascular lesion; AS: angiosarcoma; BC: breast carcinoma; * Latency interval between radigtherapy and development of cutaneous lesions; NA: not available; CE: complete excision; IB: incision biop\$y; RS: radical surgery; NRM: no recurrences or metastases from AVL.
Formatted: No underline, Font De color: Auto

Formatted: No underline, Font Ali color: Auto

Formatted: No underline, Font

Ali color: Auto Deleted: Omo

Formatted: No underline, Font color: Auto

Formatted: No underline, Font color: Auto

Formatted: No underline, Font color: Auto

Formatted: No underline, Font color: Auto

Formatted: No underline, Font color: Auto

Formatted: No underline, Font color: Auto

Formatted: No underline, Font color: Auto

Formatted: No underline, Font color: Auto

Formatted: No underline, Font color: Auto

Deleted: Omo

Formatted: No underline, Font color: Auto

Formatted: No underline, Font color: Auto

Formatted: No underline, Font color: Auto

Formatted: No underline, Font color: Auto

Formatted: No underline, Font color: Auto

Formatted: No underline, Font color: Auto

Formatted: No underline, Font color: Auto

Formatted: No underline, Font color: Auto

Formatted ... [38]

Formatted
Deleted: Omo

Formatted

Formatted

Formatted

Formatted

Formatted

Formatted

Formatted

Deleted: a

$\ldots[38]$

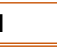

... [39]

... [40]

$\ldots[41]$

$\ldots[42]$

$\ldots[42]$
$\ldots[43]$


TABLE 2

Results of $\mathrm{p} 53$ protein expression and TP53 mutation analysis in post-radiation

Formatted: No underline, Font color: Auto atypical vascular lesions $(n=12)$ and angiosarcomas $(n=8)$

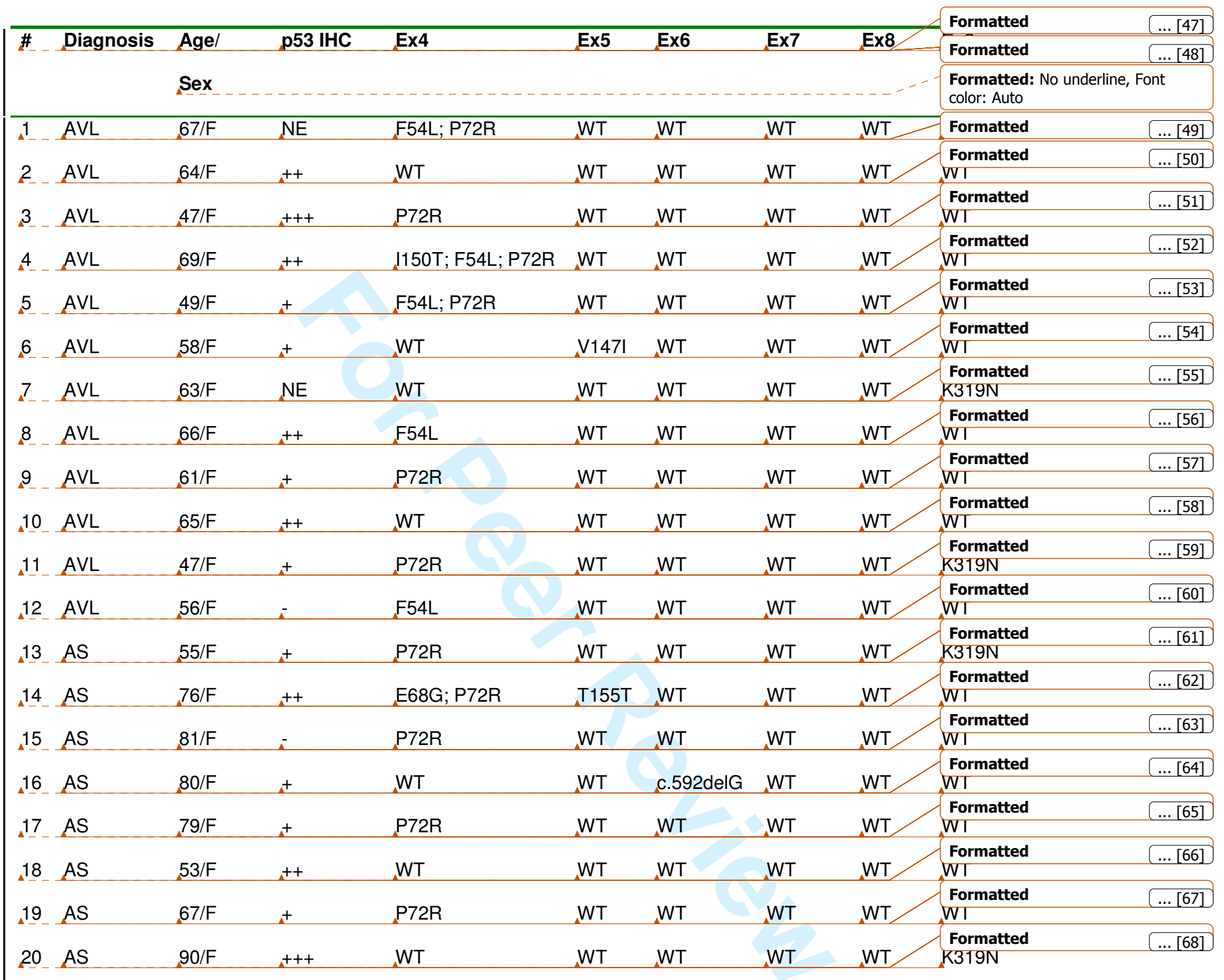

AVL: atypical vascular lesion; AS: angiosarcoma; p53 immunohistochemical (IHC) results: -, no stained 
comprised between $20 \%$ and $50 \%$; +++, the percentage of stained cells was more than $50 \%$; NE, not evaluable; WT: wild-type.

Formatted: No underline, Font color: Auto 
TABLE 3

In silico analysis of TP53 mutations by two different bioinformatic tools

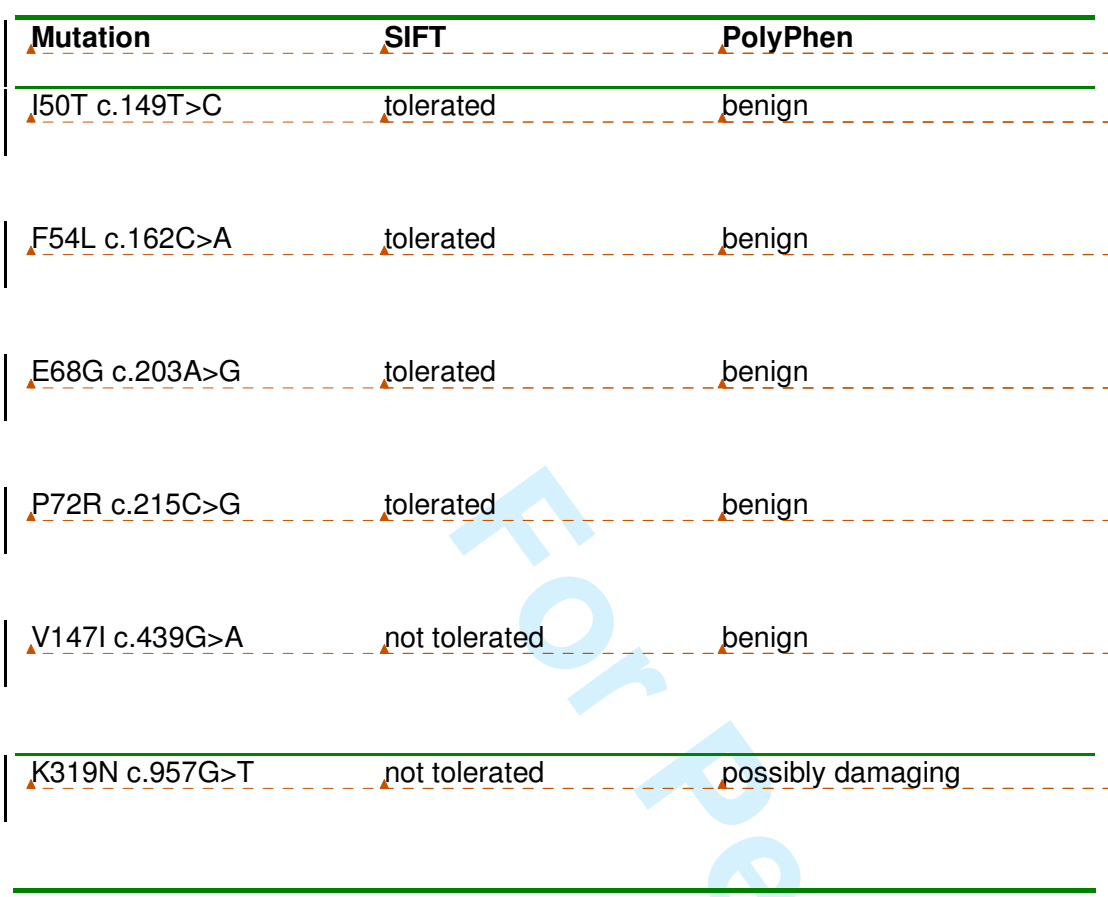

SIFT: Sorting Intolerant From Tolerant (http://blocks.fhcrc.org/sift/SIFT.html); POLYPHEN: prediction of functional effect of human nsSNPs (http://genetics.bwh.harvard.edu/pph
Formatted: No underline, Font color: Auto

Formatted: No underline, Font color: Auto

Formatted: No underline, Font

color: Auto

Formatted: No underline, Font color: Auto

Formatted: No underline, Font color: Auto

Formatted: No underline, Font color: Auto

Formatted: No underline, Font color: Auto

Formatted: No underline, Font color: Auto

Formatted: No underline, Font color: Auto

Formatted: No underline, Font color: Auto

Formatted: No underline, Font color: Auto

Formatted: No underline, Font color: Auto

Formatted: No underline, Font color: Auto

Formatted: No underline, Font color: Auto

Formatted: No underline, Font color: Auto

Formatted: No underline, Font color: Auto

Formatted: No underline, Font color: Auto

Formatted: No underline, Font color: Auto

Formatted: No underline, Font color: Auto

Formatted: No underline, Font color: Auto

Formatted: No underline, Font color: Auto

Formatted: No underline, Font color: Auto

Formatted: No underline, Font color: Auto

Formatted: Default Paragraph Font, Font: (Default) Times New Roman, 12 pt, Italian (Italy)

Deleted: /)

Formatted: No underline, Font color: Auto 


\section{FIGURE LEGENDS}

Figure 1

Atypical vascular lesion showing dilated vascular spaces in the upper dermis color: Auto

Formatted: No underline, Font color: Auto

surrounded by a moderate chronic inflammatory infiltrate (original magnification x20).

Figure 2

Atypical vascular lesion characterised by more irregular, anastomosing ${ }_{2}$ markedlydilated vascular spaces in the superficial dermis (original magnification $\times 10$ ).

Figure 3

Atypical vascular lesion, vascular channels proliferation in the upper dermis results in an upward projection of the overlying epidermis clinically featuring an exophytic papule (original magnification $\times 10$ ).

Figure 4

Atypical vascular lesion, A) vascular spaces are lined by a single layer of endothelial

Formatted: No underline, Font color: Auto cells with plump-oval or flattened nuclei; B) empty vascular lumens, surrounded by a brisk mononuclear inflammatory infiltrate; C) endothelial cells occasionally protrude into the lumen in a hobnail pattern; D) small stromal projections covered by a single layer of endothelium are detected within the vascular lumen (original magnification $x 40)$.

Figure 5 
A) High-grade angiosarcoma of irradiated breast skin (original magnification $\times 5$ ) and atypical vascular lesion (asterisk) in the same excision specimen; B) the angiosarcoma shows frankly malignant epithelioid and spindle cells with significant mitotic activity and vasoformative structures (original magnification $\times 40$ ); C) neoplastic cells show infiltration of deep dermis and so called "blood lakes" are observed (original magnification $\mathrm{x} 20$ ); $\mathrm{D}$ ) at the periphery of angiosarcoma (asterisk in A), dilated vascular spaces lined by inconspicuous endothelial cells and reminiscent of atypical vascular lesions are observed (original magnification $\times 40$ )

Figure 6

A) High-grade multifocal angiosarcoma of irradiated breast skin and atypical vascular Formatted: No underline, Font lesion (asterisk) in the same excision specimen (original magnification $\times 5$ ); B) neoplastic cells exhibit significant cytological atypia and an infiltrative pattern of growth dissecting dermal collagen bundles (original magnification x20); C) small slitlike vascular channels lined by atypical endothelial cells are seen in contiguity with more dilated, lymphatic-like vessels lined by cytologically bland endothelial cells and suggestive of atypical vascular lesions (original magnification x20); D) at higher power, enlarged nuclei and prominent nucleoli characterise severely atypical

Deleted: s endothelial cells in angiosarcoma (original magnification x40).

Formatted: Not Highlight

Figure 7

Immunohistochemical p53 staining pattern in endothelial cell nuclei of atypical vascular lesions (A-B, upper row) and angiosarcomas (C-D, upper row) is heterogeneous even in the same lesion (original magnification $\mathrm{x} 40$ ). 
Figure 8

Identification of the c.592delG mutation in exon 6 of the TP53 gene by direct DNA sequencing in one angiosarcoma sample.
Formatted: No underline, Font color: Auto

Formatted: No underline, Font color: Auto 
Page 23: [1] Formatted

Daniela

4/15/2010 3:04:00 PM

No underline, Font color: Auto

Page 23: [2] Formatted

Daniela

4/15/2010 3:04:00 PM

No underline, Font color: Auto

Page 23: [2] Formatted

Daniela

4/15/2010 3:04:00 PM

No underline, Font color: Auto

Page 23: [2] Formatted

Daniela

4/15/2010 3:04:00 PM

No underline, Font color: Auto

Page 23: [3] Formatted

Daniela

4/15/2010 3:04:00 PM

No underline, Font color: Auto

Page 23: [3] Formatted

Daniela

4/15/2010 3:04:00 PM

No underline, Font color: Auto

Page 23: [3] Formatted

Daniela

4/15/2010 3:04:00 PM

No underline, Font color: Auto

Page 23: [3] Formatted

Daniela

4/15/2010 3:04:00 PM

No underline, Font color: Auto

Page 23: [3] Formatted

Daniela

4/15/2010 3:04:00 PM

No underline, Font color: Auto

Page 23: [3] Formatted

Daniela

4/15/2010 3:04:00 PM

No underline, Font color: Auto

Page 23: [4] Formatted

Daniela

4/15/2010 3:04:00 PM

No underline, Font color: Auto

Page 23: [5] Formatted

Daniela

4/15/2010 3:04:00 PM

No underline, Font color: Auto

Page 23: [5] Formatted

Daniela

4/15/2010 3:04:00 PM

No underline, Font color: Auto

Page 23: [5] Formatted

Daniela

4/15/2010 3:04:00 PM

No underline, Font color: Auto

Page 23: [5] Formatted

Daniela

4/15/2010 3:04:00 PM

No underline, Font color: Auto

Page 23: [5] Formatted

Daniela

4/15/2010 3:04:00 PM

No underline, Font color: Auto

Page 23: [5] Formatted

Daniela

4/15/2010 3:04:00 PM

No underline, Font color: Auto

Page 23: [5] Formatted

Daniela

4/15/2010 3:04:00 PM

No underline, Font color: Auto

Page 23: [5] Formatted

Daniela

4/15/2010 3:04:00 PM

No underline, Font color: Auto

Page 23: [5] Formatted

Daniela

4/15/2010 3:04:00 PM

No underline, Font color: Auto

Page 23: [6] Formatted

Daniela

4/15/2010 3:04:00 PM

No underline, Font color: Auto 
Page 23: [6] Formatted

Daniela

4/15/2010 3:04:00 PM

No underline, Font color: Auto

Page 23: [6] Formatted

Daniela

4/15/2010 3:04:00 PM

No underline, Font color: Auto

Page 23: [7] Formatted

Daniela

4/15/2010 3:04:00 PM

No underline, Font color: Auto

Page 23: [7] Formatted

Daniela

4/15/2010 3:04:00 PM

No underline, Font color: Auto

Page 23: [7] Formatted

Daniela

4/15/2010 3:04:00 PM

No underline, Font color: Auto

Page 23: [7] Formatted

Daniela

4/15/2010 3:04:00 PM

No underline, Font color: Auto

Page 23: [7] Formatted

Daniela

4/15/2010 3:04:00 PM

No underline, Font color: Auto

Page 23: [7] Formatted

Daniela

4/15/2010 3:04:00 PM

No underline, Font color: Auto

Page 23: [8] Formatted

Daniela

4/15/2010 3:04:00 PM

No underline, Font color: Auto

Page 23: [8] Formatted

Daniela

4/15/2010 3:04:00 PM

No underline, Font color: Auto

Page 23: [8] Formatted

Daniela

4/15/2010 3:04:00 PM

No underline, Font color: Auto

Page 23: [9] Formatted

No underline, Font color: Auto
Daniela

Daniela

Daniela

4/15/2010 3:04:00 PM

Page 23: [9] Formatted

No underline, Font color: Auto

4/15/2010 3:04:00 PM

4/15/2010 3:04:00 PM
Daniela

4/15/2010 3:04:00 PM

No underline, Font color: Auto
Page 23: [9] Formatted

No underline, Font color: Auto

Page 23: [9] Formatted

Daniela

No underline, Font color: Auto

Page 23: [10] Formatted

Daniela

4/15/2010 3:04:00 PM

No underline, Font color: Auto

Page 23: [10] Formatted

Daniela

4/15/2010 3:04:00 PM

No underline, Font color: Auto

Page 23: [10] Formatted

Daniela

4/15/2010 3:04:00 PM

No underline, Font color: Auto

Page 23: [11] Formatted

Daniela

4/15/2010 3:04:00 PM

No underline, Font color: Auto 
Page 23: [11] Formatted

Daniela

4/15/2010 3:04:00 PM

No underline, Font color: Auto

Page 23: [11] Formatted

Daniela

4/15/2010 3:04:00 PM

No underline, Font color: Auto

Page 23: [11] Formatted

Daniela

4/15/2010 3:04:00 PM

Not Highlight

Page 23: [11] Formatted

Daniela

4/15/2010 3:04:00 PM

No underline, Font color: Auto

Page 23: [11] Formatted

Daniela

4/15/2010 3:04:00 PM

No underline, Font color: Auto

Page 23: [12] Formatted

Daniela

4/15/2010 3:04:00 PM

No underline, Font color: Auto

Page 23: [12] Formatted

Daniela

4/15/2010 3:04:00 PM

No underline, Font color: Auto

Page 23: [12] Formatted

Daniela

4/15/2010 3:04:00 PM

No underline, Font color: Auto

Page 23: [13] Formatted

Daniela

4/15/2010 3:04:00 PM

No underline, Font color: Auto

Page 23: [13] Formatted

Daniela

4/15/2010 3:04:00 PM

No underline, Font color: Auto

Page 23: [13] Formatted

Daniela

4/15/2010 3:04:00 PM

No underline, Font color: Auto

Page 23: [13] Formatted

Daniela

4/15/2010 3:04:00 PM

No underline, Font color: Auto

Page 23: [13] Formatted

Daniela

4/15/2010 3:04:00 PM

No underline, Font color: Auto

Page 23: [13] Formatted

Daniela

4/15/2010 3:04:00 PM

No underline, Font color: Auto

Page 23: [14] Formatted

Daniela

4/15/2010 3:04:00 PM

No underline, Font color: Auto

Page 23: [14] Formatted

Daniela

4/15/2010 3:04:00 PM

No underline, Font color: Auto

Page 23: [14] Formatted

Daniela

4/15/2010 3:04:00 PM

No underline, Font color: Auto

Page 23: [15] Formatted

Daniela

4/15/2010 3:04:00 PM

No underline, Font color: Auto

Page 23: [15] Formatted

Daniela

4/15/2010 3:04:00 PM

No underline, Font color: Auto

Page 23: [15] Formatted

Daniela

4/15/2010 3:04:00 PM

No underline, Font color: Auto

Page 23: [15] Formatted

Daniela

4/15/2010 3:04:00 PM

No underline, Font color: Auto 
Page 23: [15] Formatted Daniela

4/15/2010 3:04:00 PM

No underline, Font color: Auto

Page 23: [15] Formatted

Daniela

4/15/2010 3:04:00 PM

No underline, Font color: Auto

Page 23: [16] Formatted

Daniela

4/15/2010 3:04:00 PM

No underline, Font color: Auto

Page 23: [16] Formatted Daniela

4/15/2010 3:04:00 PM

No underline, Font color: Auto

\section{Page 23: [16] Formatted}

Daniela

4/15/2010 3:04:00 PM

No underline, Font color: Auto

Page 23: [17] Formatted

Daniela

4/15/2010 3:04:00 PM

No underline, Font color: Auto

Page 23: [17] Formatted

Daniela

4/15/2010 3:04:00 PM

No underline, Font color: Auto

Page 23: [17] Formatted

Daniela

4/15/2010 3:04:00 PM

No underline, Font color: Auto

Page 23: [17] Formatted

Daniela

4/15/2010 3:04:00 PM

No underline, Font color: Auto

Page 23: [17] Formatted

Daniela

4/15/2010 3:04:00 PM

No underline, Font color: Auto

Page 23: [17] Formatted

Daniela

4/15/2010 3:04:00 PM

No underline, Font color: Auto

Page 23: [18] Formatted

Daniela

4/15/2010 3:04:00 PM

No underline, Font color: Auto

Page 23: [18] Formatted

Daniela

4/15/2010 3:04:00 PM

No underline, Font color: Auto

Page 23: [18] Formatted

Daniela

4/15/2010 3:04:00 PM

No underline, Font color: Auto

\section{Page 23: [19] Formatted}

Daniela

4/15/2010 3:04:00 PM

No underline, Font color: Auto

Page 23: [19] Formatted

Daniela

4/15/2010 3:04:00 PM

No underline, Font color: Auto

Page 23: [19] Formatted

Daniela

4/15/2010 3:04:00 PM

No underline, Font color: Auto

Page 23: [19] Formatted

Daniela

4/15/2010 3:04:00 PM

No underline, Font color: Auto

Page 23: [19] Formatted

Daniela

4/15/2010 3:04:00 PM

No underline, Font color: Auto

Page 23: [19] Formatted

Daniela

4/15/2010 3:04:00 PM

No underline, Font color: Auto

Page 23: [20] Formatted

Daniela

4/15/2010 3:04:00 PM

No underline, Font color: Auto 
Page 23: [20] Formatted

Daniela

4/15/2010 3:04:00 PM

No underline, Font color: Auto

Page 23: [20] Formatted

Daniela

4/15/2010 3:04:00 PM

No underline, Font color: Auto

Page 23: [21] Formatted

Daniela

4/15/2010 3:04:00 PM

No underline, Font color: Auto

Page 23: [21] Formatted

Daniela

4/15/2010 3:04:00 PM

No underline, Font color: Auto

Page 23: [21] Formatted

Daniela

4/15/2010 3:04:00 PM

No underline, Font color: Auto

Page 23: [21] Formatted

Daniela

4/15/2010 3:04:00 PM

No underline, Font color: Auto

Page 23: [21] Formatted

Daniela

4/15/2010 3:04:00 PM

No underline, Font color: Auto

Page 23: [21] Formatted

Daniela

4/15/2010 3:04:00 PM

No underline, Font color: Auto

Page 23: [22] Formatted

Daniela

4/15/2010 3:04:00 PM

No underline, Font color: Auto

Page 23: [22] Formatted

Daniela

4/15/2010 3:04:00 PM

No underline, Font color: Auto

Page 23: [22] Formatted

Daniela

4/15/2010 3:04:00 PM

No underline, Font color: Auto

Page 23: [23] Formatted

Daniela

4/15/2010 3:04:00 PM

No underline, Font color: Auto

Page 23: [23] Formatted

Daniela

4/15/2010 3:04:00 PM

No underline, Font color: Auto

Page 23: [23] Formatted

Daniela

4/15/2010 3:04:00 PM

No underline, Font color: Auto

Page 23: [23] Formatted

Daniela

4/15/2010 3:04:00 PM

No underline, Font color: Auto

Page 23: [23] Formatted

Daniela

4/15/2010 3:04:00 PM

No underline, Font color: Auto

Page 23: [23] Formatted

Daniela

4/15/2010 3:04:00 PM

No underline, Font color: Auto

Page 23: [23] Formatted

Daniela

4/15/2010 3:04:00 PM

Not Highlight

Page 23: [24] Formatted

Daniela

4/15/2010 3:04:00 PM

No underline, Font color: Auto

Page 23: [24] Formatted

Daniela

4/15/2010 3:04:00 PM

No underline, Font color: Auto

Page 23: [24] Formatted

Daniela

4/15/2010 3:04:00 PM

No underline, Font color: Auto 
Page 23: [25] Formatted

Daniela

4/15/2010 3:04:00 PM

No underline, Font color: Auto

Page 23: [25] Formatted

Daniela

4/15/2010 3:04:00 PM

No underline, Font color: Auto

Page 23: [25] Formatted

Daniela

4/15/2010 3:04:00 PM

No underline, Font color: Auto

Page 23: [25] Formatted

Daniela

4/15/2010 3:04:00 PM

No underline, Font color: Auto

\section{Page 23: [25] Formatted}

Daniela

4/15/2010 3:04:00 PM

No underline, Font color: Auto

Page 23: [25] Formatted

Daniela

4/15/2010 3:04:00 PM

No underline, Font color: Auto

Page 23: [26] Formatted

Daniela

4/15/2010 3:04:00 PM

No underline, Font color: Auto

Page 23: [26] Formatted

Daniela

4/15/2010 3:04:00 PM

No underline, Font color: Auto

Page 23: [26] Formatted

Daniela

4/15/2010 3:04:00 PM

No underline, Font color: Auto

Page 23: [27] Formatted

Daniela

4/15/2010 3:04:00 PM

No underline, Font color: Auto

Page 23: [27] Formatted

Daniela

4/15/2010 3:04:00 PM

No underline, Font color: Auto

Page 23: [27] Formatted

Daniela

4/15/2010 3:04:00 PM

No underline, Font color: Auto

Page 23: [27] Formatted

Daniela

4/15/2010 3:04:00 PM

No underline, Font color: Auto

Page 23: [27] Formatted

Daniela

4/15/2010 3:04:00 PM

No underline, Font color: Auto

\section{Page 23: [27] Formatted}

Daniela

4/15/2010 3:04:00 PM

No underline, Font color: Auto

Page 23: [28] Formatted

Daniela

4/15/2010 3:04:00 PM

No underline, Font color: Auto

Page 23: [28] Formatted

Daniela

4/15/2010 3:04:00 PM

No underline, Font color: Auto

Page 23: [28] Formatted

Daniela

4/15/2010 3:04:00 PM

No underline, Font color: Auto

Page 23: [29] Formatted

Daniela

4/15/2010 3:04:00 PM

No underline, Font color: Auto

Page 23: [29] Formatted

Daniela

4/15/2010 3:04:00 PM

No underline, Font color: Auto

Page 23: [29] Formatted

Daniela

4/15/2010 3:04:00 PM

No underline, Font color: Auto 
Page 23: [29] Formatted

Daniela

4/15/2010 3:04:00 PM

No underline, Font color: Auto

Page 23: [29] Formatted

Daniela

4/15/2010 3:04:00 PM

No underline, Font color: Auto

Page 23: [29] Formatted

Daniela

4/15/2010 3:04:00 PM

No underline, Font color: Auto

Page 23: [29] Formatted

Daniela

4/15/2010 3:04:00 PM

Not Highlight

Page 23: [30] Formatted

Daniela

4/15/2010 3:04:00 PM

No underline, Font color: Auto

Page 23: [30] Formatted

Daniela

4/15/2010 3:04:00 PM

No underline, Font color: Auto

Page 23: [30] Formatted

Daniela

4/15/2010 3:04:00 PM

No underline, Font color: Auto

Page 23: [31] Formatted

Daniela

4/15/2010 3:04:00 PM

No underline, Font color: Auto

Page 23: [31] Formatted

Daniela

4/15/2010 3:04:00 PM

No underline, Font color: Auto

Page 23: [31] Formatted

Daniela

4/15/2010 3:04:00 PM

No underline, Font color: Auto

Page 23: [31] Formatted

Daniela

4/15/2010 3:04:00 PM

No underline, Font color: Auto

Page 23: [31] Formatted

Daniela

4/15/2010 3:04:00 PM

No underline, Font color: Auto

Page 23: [31] Formatted

Daniela

4/15/2010 3:04:00 PM

No underline, Font color: Auto

Page 23: [31] Formatted

Daniela

4/15/2010 3:04:00 PM

Not Highlight

Page 23: [32] Formatted

Daniela

4/15/2010 3:04:00 PM

No underline, Font color: Auto

Page 23: [32] Formatted

Daniela

4/15/2010 3:04:00 PM

No underline, Font color: Auto

Page 23: [32] Formatted

Daniela

4/15/2010 3:04:00 PM

No underline, Font color: Auto

Page 23: [33] Formatted

Daniela

4/15/2010 3:04:00 PM

No underline, Font color: Auto

Page 23: [33] Formatted

Daniela

4/15/2010 3:04:00 PM

No underline, Font color: Auto

Page 23: [33] Formatted

Daniela

4/15/2010 3:04:00 PM

No underline, Font color: Auto

Page 23: [33] Formatted

Daniela

4/15/2010 3:04:00 PM

No underline, Font color: Auto 
Page 23: [33] Formatted Daniela

4/15/2010 3:04:00 PM

No underline, Font color: Auto

Page 23: [33] Formatted

Daniela

4/15/2010 3:04:00 PM

No underline, Font color: Auto

Page 23: [34] Formatted

Daniela

4/15/2010 3:04:00 PM

No underline, Font color: Auto

Page 23: [34] Formatted Daniela

4/15/2010 3:04:00 PM

No underline, Font color: Auto

\section{Page 23: [34] Formatted}

Daniela

4/15/2010 3:04:00 PM

No underline, Font color: Auto

Page 23: [35] Formatted

Daniela

4/15/2010 3:04:00 PM

No underline, Font color: Auto

Page 23: [35] Formatted

Daniela

4/15/2010 3:04:00 PM

No underline, Font color: Auto

Page 23: [35] Formatted

Daniela

4/15/2010 3:04:00 PM

No underline, Font color: Auto

Page 23: [35] Formatted

Daniela

4/15/2010 3:04:00 PM

No underline, Font color: Auto

Page 23: [35] Formatted

Daniela

4/15/2010 3:04:00 PM

No underline, Font color: Auto

Page 23: [35] Formatted

Daniela

4/15/2010 3:04:00 PM

No underline, Font color: Auto

Page 23: [36] Formatted

Daniela

4/15/2010 3:04:00 PM

No underline, Font color: Auto

Page 23: [36] Formatted

Daniela

4/15/2010 3:04:00 PM

No underline, Font color: Auto

Page 23: [36] Formatted

Daniela

4/15/2010 3:04:00 PM

No underline, Font color: Auto

Page 23: [37] Formatted

Daniela

4/15/2010 3:04:00 PM

No underline, Font color: Auto

Page 23: [37] Formatted

Daniela

4/15/2010 3:04:00 PM

No underline, Font color: Auto

Page 23: [37] Formatted

Daniela

4/15/2010 3:04:00 PM

No underline, Font color: Auto

Page 23: [37] Formatted

Daniela

4/15/2010 3:04:00 PM

No underline, Font color: Auto

Page 23: [37] Formatted

Daniela

4/15/2010 3:04:00 PM

No underline, Font color: Auto

Page 23: [37] Formatted

Daniela

4/15/2010 3:04:00 PM

No underline, Font color: Auto

Page 24: [38] Formatted

Daniela

4/15/2010 3:04:00 PM

No underline, Font color: Auto 
Page 24: [39] Formatted

Daniela

4/15/2010 3:04:00 PM

No underline, Font color: Auto

Page 24: [40] Formatted

Daniela

4/15/2010 3:04:00 PM

No underline, Font color: Auto

Page 24: [41] Formatted

Daniela

4/15/2010 3:04:00 PM

No underline, Font color: Auto

Page 24: [42] Formatted

Daniela

4/15/2010 3:04:00 PM

No underline, Font color: Auto

Page 24: [43] Formatted

Daniela

4/15/2010 3:04:00 PM

No underline, Font color: Auto

Page 24: [44] Formatted

Daniela

4/15/2010 3:04:00 PM

No underline, Font color: Auto

Page 24: [45] Formatted

Daniela

4/15/2010 3:04:00 PM

No underline, Font color: Auto

Page 24: [46] Formatted

Daniela

4/15/2010 3:04:00 PM

No underline, Font color: Auto

Page 25: [47] Formatted

Daniela

4/15/2010 3:04:00 PM

No underline, Font color: Auto

Page 25: [47] Formatted

Daniela

4/15/2010 3:04:00 PM

No underline, Font color: Auto

Page 25: [47] Formatted

Daniela

4/15/2010 3:04:00 PM

No underline, Font color: Auto

Page 25: [48] Formatted

Daniela

4/15/2010 3:04:00 PM

No underline, Font color: Auto

Page 25: [48] Formatted

Daniela

4/15/2010 3:04:00 PM

No underline, Font color: Auto

Page 25: [48] Formatted

Daniela

4/15/2010 3:04:00 PM

No underline, Font color: Auto

Page 25: [48] Formatted

Daniela

4/15/2010 3:04:00 PM

No underline, Font color: Auto

Page 25: [48] Formatted

Daniela

4/15/2010 3:04:00 PM

No underline, Font color: Auto

Page 25: [48] Formatted

Daniela

4/15/2010 3:04:00 PM

No underline, Font color: Auto

Page 25: [48] Formatted

Daniela

4/15/2010 3:04:00 PM

No underline, Font color: Auto

Page 25: [49] Formatted

Daniela

4/15/2010 3:04:00 PM

No underline, Font color: Auto

Page 25: [49] Formatted

Daniela

4/15/2010 3:04:00 PM

No underline, Font color: Auto

Page 25: [49] Formatted

Daniela

4/15/2010 3:04:00 PM

No underline, Font color: Auto 
Page 25: [49] Formatted Daniela

4/15/2010 3:04:00 PM

No underline, Font color: Auto

Page 25: [49] Formatted

Daniela

4/15/2010 3:04:00 PM

No underline, Font color: Auto

Page 25: [49] Formatted

Daniela

4/15/2010 3:04:00 PM

No underline, Font color: Auto

Page 25: [49] Formatted Daniela

4/15/2010 3:04:00 PM

No underline, Font color: Auto

\section{Page 25: [49] Formatted}

Daniela

4/15/2010 3:04:00 PM

No underline, Font color: Auto

Page 25: [49] Formatted

Daniela

4/15/2010 3:04:00 PM

No underline, Font color: Auto

Page 25: [49] Formatted

Daniela

4/15/2010 3:04:00 PM

No underline, Font color: Auto

Page 25: [50] Formatted

Daniela

4/15/2010 3:04:00 PM

No underline, Font color: Auto

Page 25: [50] Formatted

Daniela

4/15/2010 3:04:00 PM

No underline, Font color: Auto

Page 25: [50] Formatted

Daniela

4/15/2010 3:04:00 PM

No underline, Font color: Auto

Page 25: [50] Formatted

Daniela

4/15/2010 3:04:00 PM

No underline, Font color: Auto

Page 25: [50] Formatted

Daniela

4/15/2010 3:04:00 PM

No underline, Font color: Auto

Page 25: [50] Formatted

Daniela

4/15/2010 3:04:00 PM

No underline, Font color: Auto

Page 25: [50] Formatted

Daniela

4/15/2010 3:04:00 PM

No underline, Font color: Auto

Page 25: [50] Formatted

Daniela

4/15/2010 3:04:00 PM

No underline, Font color: Auto

Page 25: [50] Formatted

Daniela

4/15/2010 3:04:00 PM

No underline, Font color: Auto

Page 25: [50] Formatted

Daniela

4/15/2010 3:04:00 PM

No underline, Font color: Auto

Page 25: [51] Formatted

Daniela

4/15/2010 3:04:00 PM

No underline, Font color: Auto

Page 25: [51] Formatted

Daniela

4/15/2010 3:04:00 PM

No underline, Font color: Auto

Page 25: [51] Formatted

Daniela

4/15/2010 3:04:00 PM

No underline, Font color: Auto

Page 25: [51] Formatted

Daniela

4/15/2010 3:04:00 PM

No underline, Font color: Auto 
Page 25: [51] Formatted

Daniela

4/15/2010 3:04:00 PM

No underline, Font color: Auto

Page 25: [51] Formatted

Daniela

4/15/2010 3:04:00 PM

No underline, Font color: Auto

Page 25: [51] Formatted

Daniela

4/15/2010 3:04:00 PM

No underline, Font color: Auto

Page 25: [51] Formatted

Daniela

4/15/2010 3:04:00 PM

No underline, Font color: Auto

Page 25: [51] Formatted

Daniela

4/15/2010 3:04:00 PM

No underline, Font color: Auto

Page 25: [51] Formatted

Daniela

4/15/2010 3:04:00 PM

No underline, Font color: Auto

Page 25: [52] Formatted

Daniela

4/15/2010 3:04:00 PM

No underline, Font color: Auto

Page 25: [52] Formatted

Daniela

4/15/2010 3:04:00 PM

No underline, Font color: Auto

Page 25: [52] Formatted

Daniela

4/15/2010 3:04:00 PM

No underline, Font color: Auto

Page 25: [52] Formatted

Daniela

4/15/2010 3:04:00 PM

No underline, Font color: Auto

Page 25: [52] Formatted

Daniela

4/15/2010 3:04:00 PM

No underline, Font color: Auto

Page 25: [52] Formatted

Daniela

4/15/2010 3:04:00 PM

No underline, Font color: Auto

Page 25: [52] Formatted

Daniela

4/15/2010 3:04:00 PM

No underline, Font color: Auto

Page 25: [52] Formatted

Daniela

4/15/2010 3:04:00 PM

No underline, Font color: Auto

Page 25: [52] Formatted

Daniela

4/15/2010 3:04:00 PM

No underline, Font color: Auto

Page 25: [52] Formatted

Daniela

4/15/2010 3:04:00 PM

No underline, Font color: Auto

Page 25: [53] Formatted

Daniela

4/15/2010 3:04:00 PM

No underline, Font color: Auto

Page 25: [53] Formatted

Daniela

4/15/2010 3:04:00 PM

No underline, Font color: Auto

Page 25: [53] Formatted

Daniela

4/15/2010 3:04:00 PM

No underline, Font color: Auto

Page 25: [53] Formatted

Daniela

4/15/2010 3:04:00 PM

No underline, Font color: Auto

Page 25: [53] Formatted

Daniela

4/15/2010 3:04:00 PM

No underline, Font color: Auto 
Page 25: [53] Formatted Daniela

4/15/2010 3:04:00 PM

No underline, Font color: Auto

Page 25: [53] Formatted

Daniela

4/15/2010 3:04:00 PM

No underline, Font color: Auto

Page 25: [53] Formatted

Daniela

4/15/2010 3:04:00 PM

No underline, Font color: Auto

Page 25: [53] Formatted Daniela

4/15/2010 3:04:00 PM

No underline, Font color: Auto

\section{Page 25: [53] Formatted}

Daniela

4/15/2010 3:04:00 PM

No underline, Font color: Auto

Page 25: [54] Formatted

Daniela

4/15/2010 3:04:00 PM

No underline, Font color: Auto

Page 25: [54] Formatted

Daniela

4/15/2010 3:04:00 PM

No underline, Font color: Auto

Page 25: [54] Formatted

Daniela

4/15/2010 3:04:00 PM

No underline, Font color: Auto

Page 25: [54] Formatted

Daniela

4/15/2010 3:04:00 PM

No underline, Font color: Auto

Page 25: [54] Formatted

Daniela

4/15/2010 3:04:00 PM

No underline, Font color: Auto

Page 25: [54] Formatted

Daniela

4/15/2010 3:04:00 PM

No underline, Font color: Auto

Page 25: [54] Formatted

Daniela

4/15/2010 3:04:00 PM

No underline, Font color: Auto

Page 25: [54] Formatted

Daniela

4/15/2010 3:04:00 PM

No underline, Font color: Auto

Page 25: [54] Formatted

Daniela

4/15/2010 3:04:00 PM

No underline, Font color: Auto

Page 25: [54] Formatted

Daniela

4/15/2010 3:04:00 PM

No underline, Font color: Auto

Page 25: [55] Formatted

Daniela

4/15/2010 3:04:00 PM

No underline, Font color: Auto

Page 25: [55] Formatted

Daniela

4/15/2010 3:04:00 PM

No underline, Font color: Auto

Page 25: [55] Formatted

Daniela

4/15/2010 3:04:00 PM

No underline, Font color: Auto

Page 25: [55] Formatted

Daniela

4/15/2010 3:04:00 PM

No underline, Font color: Auto

Page 25: [55] Formatted

Daniela

4/15/2010 3:04:00 PM

No underline, Font color: Auto

Page 25: [55] Formatted

Daniela

4/15/2010 3:04:00 PM

No underline, Font color: Auto 
Page 25: [55] Formatted

Daniela

4/15/2010 3:04:00 PM

No underline, Font color: Auto

Page 25: [55] Formatted

Daniela

4/15/2010 3:04:00 PM

No underline, Font color: Auto

Page 25: [55] Formatted

Daniela

4/15/2010 3:04:00 PM

No underline, Font color: Auto

Page 25: [55] Formatted

Daniela

4/15/2010 3:04:00 PM

No underline, Font color: Auto

Page 25: [56] Formatted

Daniela

4/15/2010 3:04:00 PM

No underline, Font color: Auto

Page 25: [56] Formatted

Daniela

4/15/2010 3:04:00 PM

No underline, Font color: Auto

Page 25: [56] Formatted

Daniela

4/15/2010 3:04:00 PM

No underline, Font color: Auto

Page 25: [56] Formatted

Daniela

4/15/2010 3:04:00 PM

No underline, Font color: Auto

Page 25: [56] Formatted

Daniela

4/15/2010 3:04:00 PM

No underline, Font color: Auto

Page 25: [56] Formatted

Daniela

4/15/2010 3:04:00 PM

No underline, Font color: Auto

Page 25: [56] Formatted

Daniela

4/15/2010 3:04:00 PM

No underline, Font color: Auto

Page 25: [56] Formatted

Daniela

4/15/2010 3:04:00 PM

No underline, Font color: Auto

Page 25: [56] Formatted

Daniela

4/15/2010 3:04:00 PM

No underline, Font color: Auto

Page 25: [56] Formatted

Daniela

4/15/2010 3:04:00 PM

No underline, Font color: Auto

Page 25: [57] Formatted

Daniela

4/15/2010 3:04:00 PM

No underline, Font color: Auto

Page 25: [57] Formatted

Daniela

4/15/2010 3:04:00 PM

No underline, Font color: Auto

Page 25: [57] Formatted

Daniela

4/15/2010 3:04:00 PM

No underline, Font color: Auto

Page 25: [57] Formatted

Daniela

4/15/2010 3:04:00 PM

No underline, Font color: Auto

Page 25: [57] Formatted

Daniela

4/15/2010 3:04:00 PM

No underline, Font color: Auto

Page 25: [57] Formatted

Daniela

4/15/2010 3:04:00 PM

No underline, Font color: Auto

Page 25: [57] Formatted

Daniela

4/15/2010 3:04:00 PM

No underline, Font color: Auto 
Page 25: [57] Formatted Daniela

4/15/2010 3:04:00 PM

No underline, Font color: Auto

Page 25: [57] Formatted

Daniela

4/15/2010 3:04:00 PM

No underline, Font color: Auto

Page 25: [57] Formatted

Daniela

4/15/2010 3:04:00 PM

No underline, Font color: Auto

Page 25: [58] Formatted Daniela

4/15/2010 3:04:00 PM

No underline, Font color: Auto

\section{Page 25: [58] Formatted}

Daniela

4/15/2010 3:04:00 PM

No underline, Font color: Auto

Page 25: [58] Formatted

Daniela

4/15/2010 3:04:00 PM

No underline, Font color: Auto

Page 25: [58] Formatted

Daniela

4/15/2010 3:04:00 PM

No underline, Font color: Auto

Page 25: [58] Formatted

Daniela

4/15/2010 3:04:00 PM

No underline, Font color: Auto

Page 25: [58] Formatted

Daniela

4/15/2010 3:04:00 PM

No underline, Font color: Auto

Page 25: [58] Formatted

Daniela

4/15/2010 3:04:00 PM

No underline, Font color: Auto

Page 25: [58] Formatted

Daniela

4/15/2010 3:04:00 PM

No underline, Font color: Auto

Page 25: [58] Formatted

Daniela

4/15/2010 3:04:00 PM

No underline, Font color: Auto

Page 25: [58] Formatted

Daniela

4/15/2010 3:04:00 PM

No underline, Font color: Auto

Page 25: [59] Formatted

Daniela

4/15/2010 3:04:00 PM

No underline, Font color: Auto

Page 25: [59] Formatted

Daniela

4/15/2010 3:04:00 PM

No underline, Font color: Auto

Page 25: [59] Formatted

Daniela

4/15/2010 3:04:00 PM

No underline, Font color: Auto

Page 25: [59] Formatted

Daniela

4/15/2010 3:04:00 PM

No underline, Font color: Auto

Page 25: [59] Formatted

Daniela

4/15/2010 3:04:00 PM

No underline, Font color: Auto

Page 25: [59] Formatted

Daniela

4/15/2010 3:04:00 PM

No underline, Font color: Auto

Page 25: [59] Formatted

Daniela

4/15/2010 3:04:00 PM

No underline, Font color: Auto

Page 25: [59] Formatted

Daniela

4/15/2010 3:04:00 PM

No underline, Font color: Auto 
Page 25: [59] Formatted

Daniela

4/15/2010 3:04:00 PM

No underline, Font color: Auto

Page 25: [59] Formatted

Daniela

4/15/2010 3:04:00 PM

No underline, Font color: Auto

Page 25: [60] Formatted

Daniela

4/15/2010 3:04:00 PM

No underline, Font color: Auto

Page 25: [60] Formatted

Daniela

4/15/2010 3:04:00 PM

No underline, Font color: Auto

Page 25: [60] Formatted

Daniela

4/15/2010 3:04:00 PM

No underline, Font color: Auto

Page 25: [60] Formatted

Daniela

4/15/2010 3:04:00 PM

No underline, Font color: Auto

Page 25: [60] Formatted

Daniela

4/15/2010 3:04:00 PM

No underline, Font color: Auto

Page 25: [60] Formatted

Daniela

4/15/2010 3:04:00 PM

No underline, Font color: Auto

Page 25: [60] Formatted

Daniela

4/15/2010 3:04:00 PM

No underline, Font color: Auto

Page 25: [60] Formatted

Daniela

4/15/2010 3:04:00 PM

No underline, Font color: Auto

Page 25: [60] Formatted

Daniela

4/15/2010 3:04:00 PM

No underline, Font color: Auto

Page 25: [60] Formatted

Daniela

4/15/2010 3:04:00 PM

No underline, Font color: Auto

Page 25: [61] Formatted

Daniela

4/15/2010 3:04:00 PM

No underline, Font color: Auto

Page 25: [61] Formatted

Daniela

4/15/2010 3:04:00 PM

No underline, Font color: Auto

Page 25: [61] Formatted

Daniela

4/15/2010 3:04:00 PM

No underline, Font color: Auto

Page 25: [61] Formatted

Daniela

4/15/2010 3:04:00 PM

No underline, Font color: Auto

Page 25: [61] Formatted

Daniela

4/15/2010 3:04:00 PM

No underline, Font color: Auto

Page 25: [61] Formatted

Daniela

4/15/2010 3:04:00 PM

No underline, Font color: Auto

Page 25: [61] Formatted

Daniela

4/15/2010 3:04:00 PM

No underline, Font color: Auto

Page 25: [61] Formatted

Daniela

4/15/2010 3:04:00 PM

No underline, Font color: Auto

Page 25: [61] Formatted

Daniela

4/15/2010 3:04:00 PM

No underline, Font color: Auto 
Page 25: [61] Formatted Daniela

4/15/2010 3:04:00 PM

No underline, Font color: Auto

Page 25: [62] Formatted

Daniela

4/15/2010 3:04:00 PM

No underline, Font color: Auto

Page 25: [62] Formatted

Daniela

4/15/2010 3:04:00 PM

No underline, Font color: Auto

Page 25: [62] Formatted Daniela

4/15/2010 3:04:00 PM

No underline, Font color: Auto

\section{Page 25: [62] Formatted}

Daniela

4/15/2010 3:04:00 PM

No underline, Font color: Auto

Page 25: [62] Formatted

Daniela

4/15/2010 3:04:00 PM

No underline, Font color: Auto

Page 25: [62] Formatted

Daniela

4/15/2010 3:04:00 PM

No underline, Font color: Auto

Page 25: [62] Formatted

Daniela

4/15/2010 3:04:00 PM

No underline, Font color: Auto

Page 25: [62] Formatted

Daniela

4/15/2010 3:04:00 PM

No underline, Font color: Auto

Page 25: [62] Formatted

Daniela

4/15/2010 3:04:00 PM

No underline, Font color: Auto

Page 25: [62] Formatted

Daniela

4/15/2010 3:04:00 PM

No underline, Font color: Auto

Page 25: [63] Formatted

Daniela

4/15/2010 3:04:00 PM

No underline, Font color: Auto

Page 25: [63] Formatted

Daniela

4/15/2010 3:04:00 PM

No underline, Font color: Auto

Page 25: [63] Formatted

Daniela

4/15/2010 3:04:00 PM

No underline, Font color: Auto

Page 25: [63] Formatted

Daniela

4/15/2010 3:04:00 PM

No underline, Font color: Auto

Page 25: [63] Formatted

Daniela

4/15/2010 3:04:00 PM

No underline, Font color: Auto

Page 25: [63] Formatted

Daniela

4/15/2010 3:04:00 PM

No underline, Font color: Auto

Page 25: [63] Formatted

Daniela

4/15/2010 3:04:00 PM

No underline, Font color: Auto

Page 25: [63] Formatted

Daniela

4/15/2010 3:04:00 PM

No underline, Font color: Auto

Page 25: [63] Formatted

Daniela

4/15/2010 3:04:00 PM

No underline, Font color: Auto

Page 25: [63] Formatted

Daniela

4/15/2010 3:04:00 PM

No underline, Font color: Auto 
Page 25: [64] Formatted

Daniela

4/15/2010 3:04:00 PM

No underline, Font color: Auto

Page 25: [64] Formatted

Daniela

4/15/2010 3:04:00 PM

No underline, Font color: Auto

Page 25: [64] Formatted

Daniela

4/15/2010 3:04:00 PM

No underline, Font color: Auto

Page 25: [64] Formatted

Daniela

4/15/2010 3:04:00 PM

No underline, Font color: Auto

Page 25: [64] Formatted

Daniela

4/15/2010 3:04:00 PM

No underline, Font color: Auto

Page 25: [64] Formatted

Daniela

4/15/2010 3:04:00 PM

No underline, Font color: Auto

Page 25: [64] Formatted

Daniela

4/15/2010 3:04:00 PM

No underline, Font color: Auto

Page 25: [64] Formatted

Daniela

4/15/2010 3:04:00 PM

No underline, Font color: Auto

Page 25: [64] Formatted

Daniela

4/15/2010 3:04:00 PM

No underline, Font color: Auto

Page 25: [64] Formatted

Daniela

4/15/2010 3:04:00 PM

No underline, Font color: Auto

Page 25: [65] Formatted

Daniela

4/15/2010 3:04:00 PM

No underline, Font color: Auto

Page 25: [65] Formatted

Daniela

4/15/2010 3:04:00 PM

No underline, Font color: Auto

Page 25: [65] Formatted

Daniela

4/15/2010 3:04:00 PM

No underline, Font color: Auto

Page 25: [65] Formatted

Daniela

4/15/2010 3:04:00 PM

No underline, Font color: Auto

Page 25: [65] Formatted

Daniela

4/15/2010 3:04:00 PM

No underline, Font color: Auto

Page 25: [65] Formatted

Daniela

4/15/2010 3:04:00 PM

No underline, Font color: Auto

Page 25: [65] Formatted

Daniela

4/15/2010 3:04:00 PM

No underline, Font color: Auto

Page 25: [65] Formatted

Daniela

4/15/2010 3:04:00 PM

No underline, Font color: Auto

Page 25: [65] Formatted

Daniela

4/15/2010 3:04:00 PM

No underline, Font color: Auto

Page 25: [65] Formatted

Daniela

4/15/2010 3:04:00 PM

No underline, Font color: Auto

Page 25: [66] Formatted

Daniela

4/15/2010 3:04:00 PM

No underline, Font color: Auto 
Page 25: [66] Formatted Daniela

4/15/2010 3:04:00 PM

No underline, Font color: Auto

Page 25: [66] Formatted

Daniela

4/15/2010 3:04:00 PM

No underline, Font color: Auto

Page 25: [66] Formatted

Daniela

4/15/2010 3:04:00 PM

No underline, Font color: Auto

Page 25: [66] Formatted Daniela

4/15/2010 3:04:00 PM

No underline, Font color: Auto

\section{Page 25: [66] Formatted}

Daniela

4/15/2010 3:04:00 PM

No underline, Font color: Auto

Page 25: [66] Formatted

Daniela

4/15/2010 3:04:00 PM

No underline, Font color: Auto

Page 25: [66] Formatted

Daniela

4/15/2010 3:04:00 PM

No underline, Font color: Auto

Page 25: [66] Formatted

Daniela

4/15/2010 3:04:00 PM

No underline, Font color: Auto

Page 25: [66] Formatted

Daniela

4/15/2010 3:04:00 PM

No underline, Font color: Auto

Page 25: [67] Formatted

Daniela

4/15/2010 3:04:00 PM

No underline, Font color: Auto

Page 25: [67] Formatted

Daniela

4/15/2010 3:04:00 PM

No underline, Font color: Auto

Page 25: [67] Formatted

Daniela

4/15/2010 3:04:00 PM

No underline, Font color: Auto

Page 25: [67] Formatted

Daniela

4/15/2010 3:04:00 PM

No underline, Font color: Auto

Page 25: [67] Formatted

Daniela

4/15/2010 3:04:00 PM

No underline, Font color: Auto

Page 25: [67] Formatted

Daniela

4/15/2010 3:04:00 PM

No underline, Font color: Auto

Page 25: [67] Formatted

Daniela

4/15/2010 3:04:00 PM

No underline, Font color: Auto

Page 25: [67] Formatted

Daniela

4/15/2010 3:04:00 PM

No underline, Font color: Auto

Page 25: [67] Formatted

Daniela

4/15/2010 3:04:00 PM

No underline, Font color: Auto

Page 25: [67] Formatted

Daniela

4/15/2010 3:04:00 PM

No underline, Font color: Auto

Page 25: [68] Formatted

Daniela

4/15/2010 3:04:00 PM

No underline, Font color: Auto

Page 25: [68] Formatted

Daniela

4/15/2010 3:04:00 PM

No underline, Font color: Auto 
Page 25: [68] Formatted

Daniela

4/15/2010 3:04:00 PM

No underline, Font color: Auto

Page 25: [68] Formatted

Daniela

4/15/2010 3:04:00 PM

No underline, Font color: Auto

Page 25: [68] Formatted

Daniela

4/15/2010 3:04:00 PM

No underline, Font color: Auto

Page 25: [68] Formatted

Daniela

4/15/2010 3:04:00 PM

No underline, Font color: Auto

Page 25: [68] Formatted

Daniela

4/15/2010 3:04:00 PM

No underline, Font color: Auto

Page 25: [68] Formatted

Daniela

4/15/2010 3:04:00 PM

No underline, Font color: Auto

Page 25: [68] Formatted

Daniela

4/15/2010 3:04:00 PM

No underline, Font color: Auto

Page 25: [68] Formatted

Daniela

4/15/2010 3:04:00 PM

No underline, Font color: Auto 


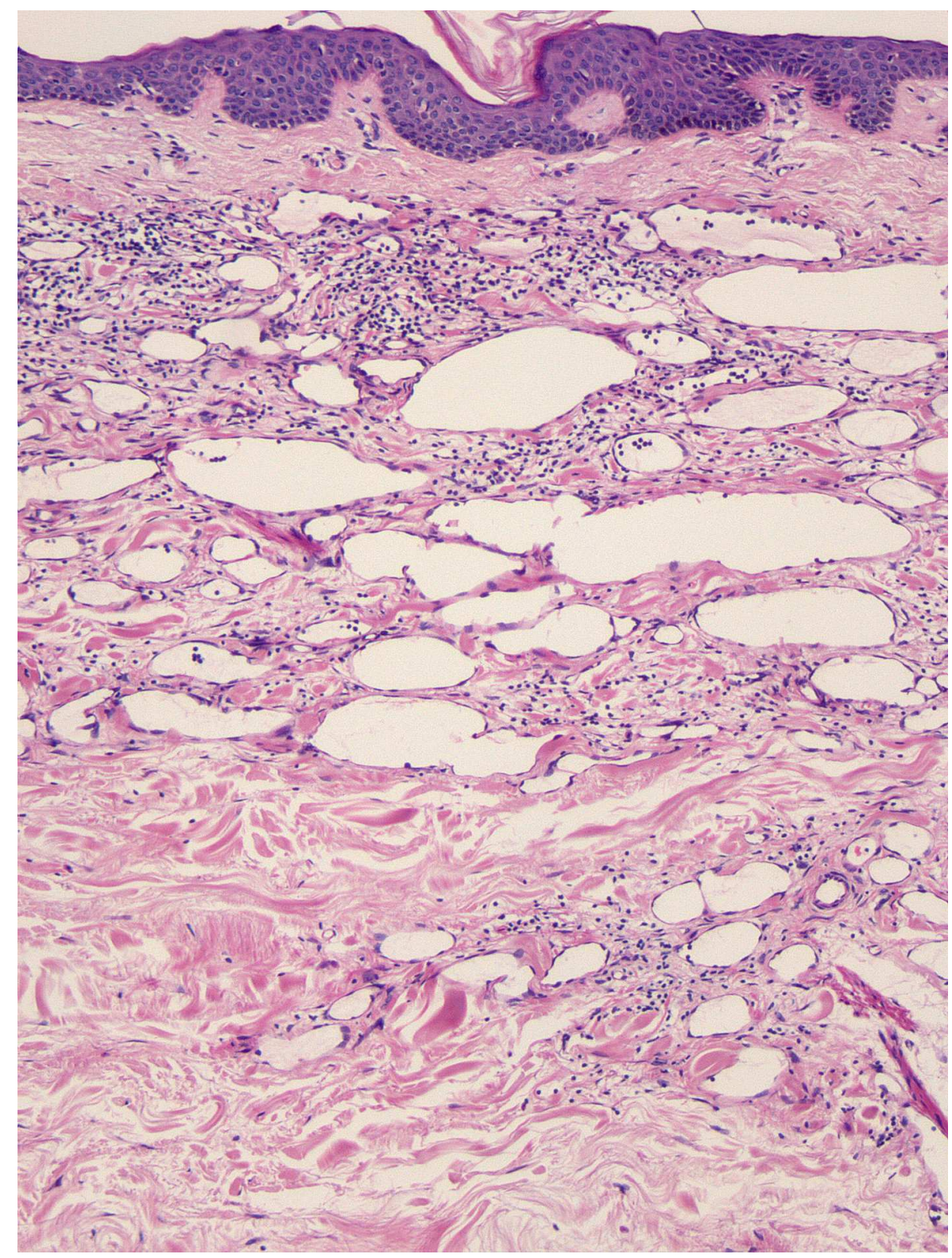

$119 \times 160 \mathrm{~mm}(300 \times 300 \mathrm{DPI})$ 


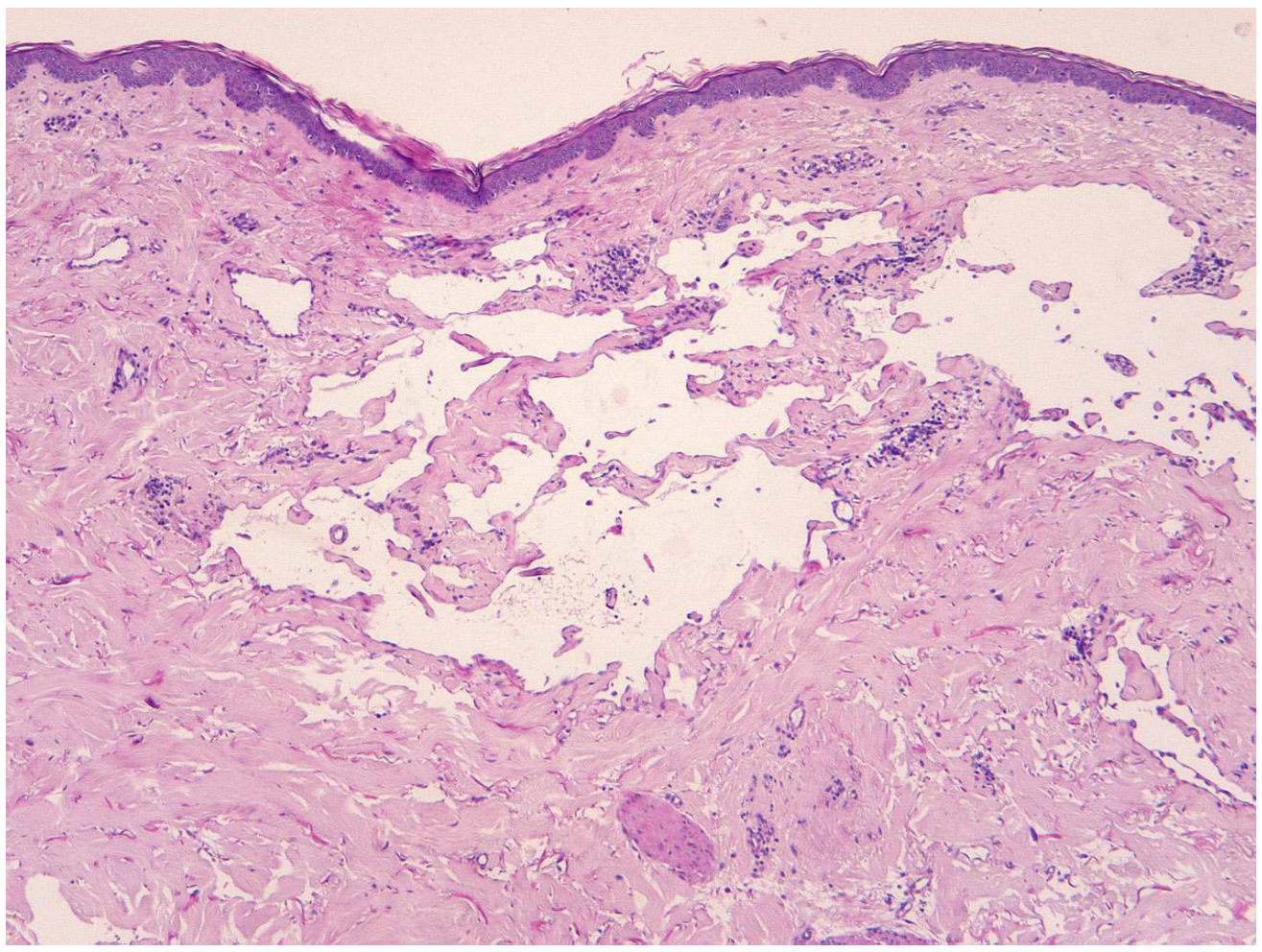

$119 \times 90 \mathrm{~mm}(300 \times 300$ DPI $)$ 


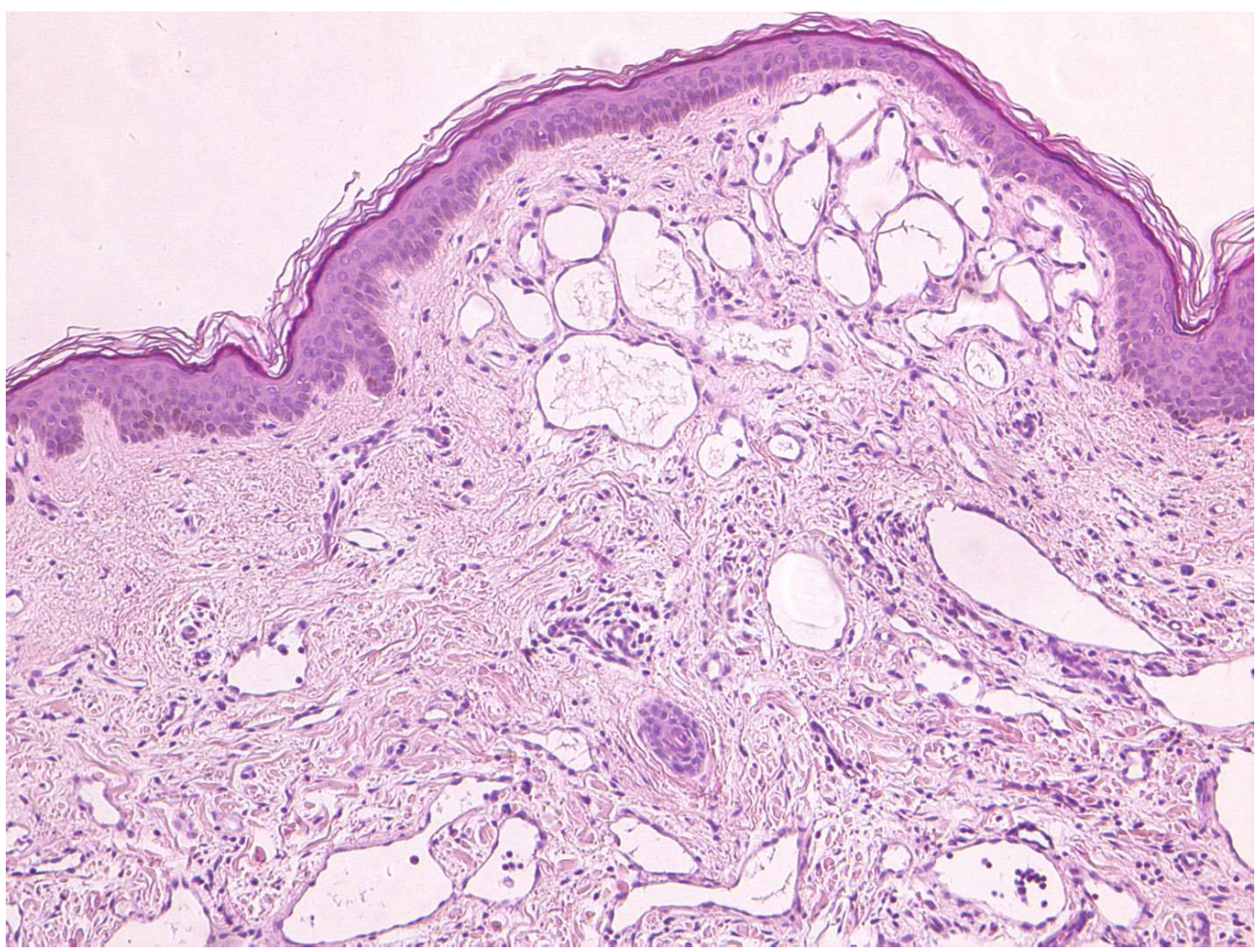

$119 \times 90 \mathrm{~mm}(300 \times 300$ DPI $)$ 

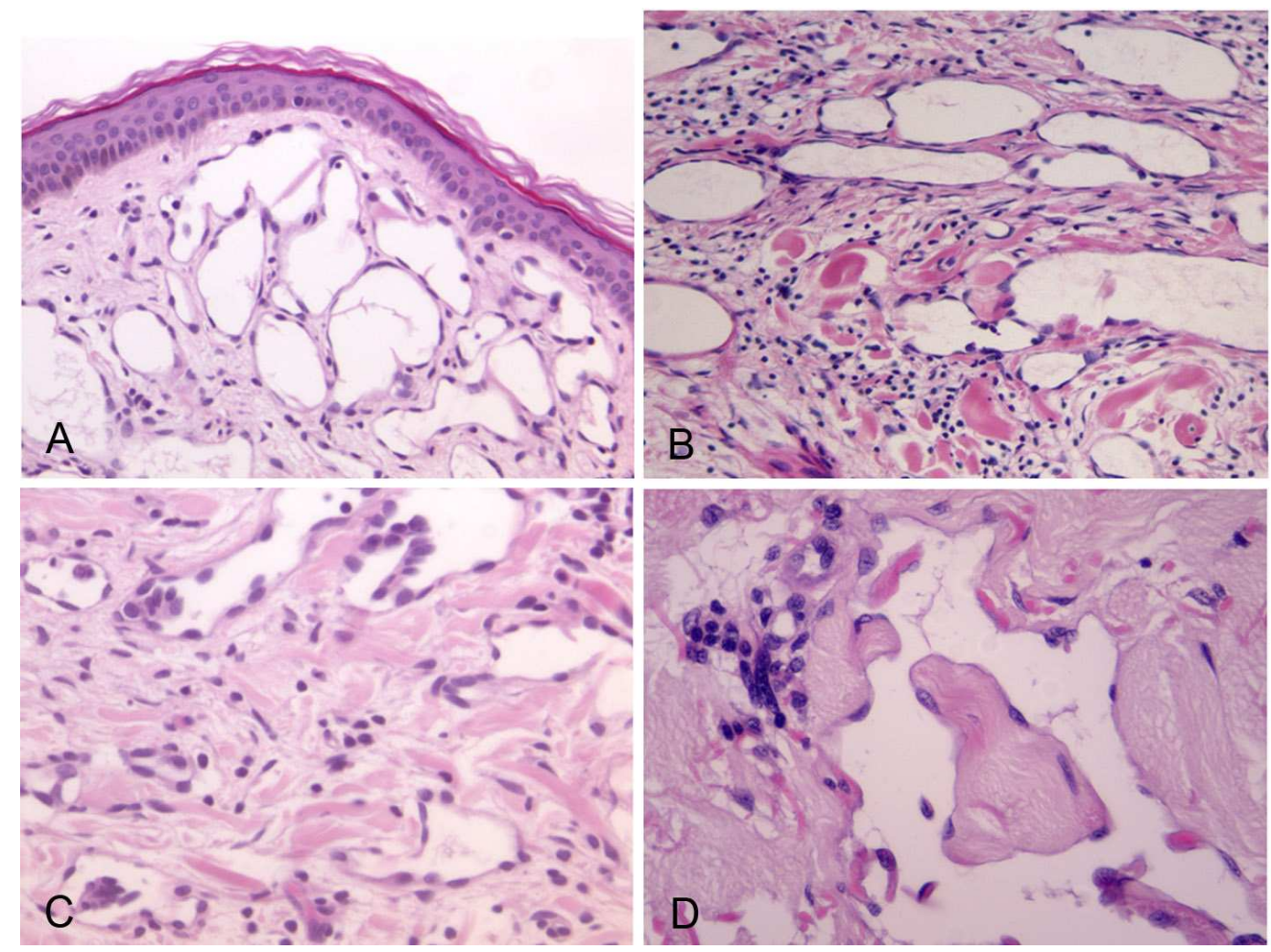

$119 \times 90 \mathrm{~mm}(300 \times 300$ DPI $)$ 


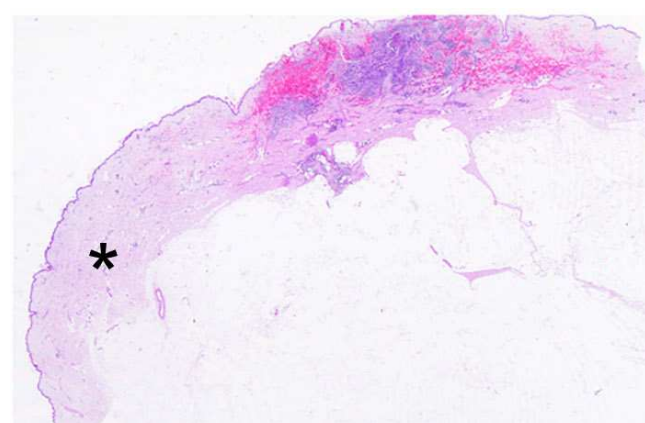

\section{A}
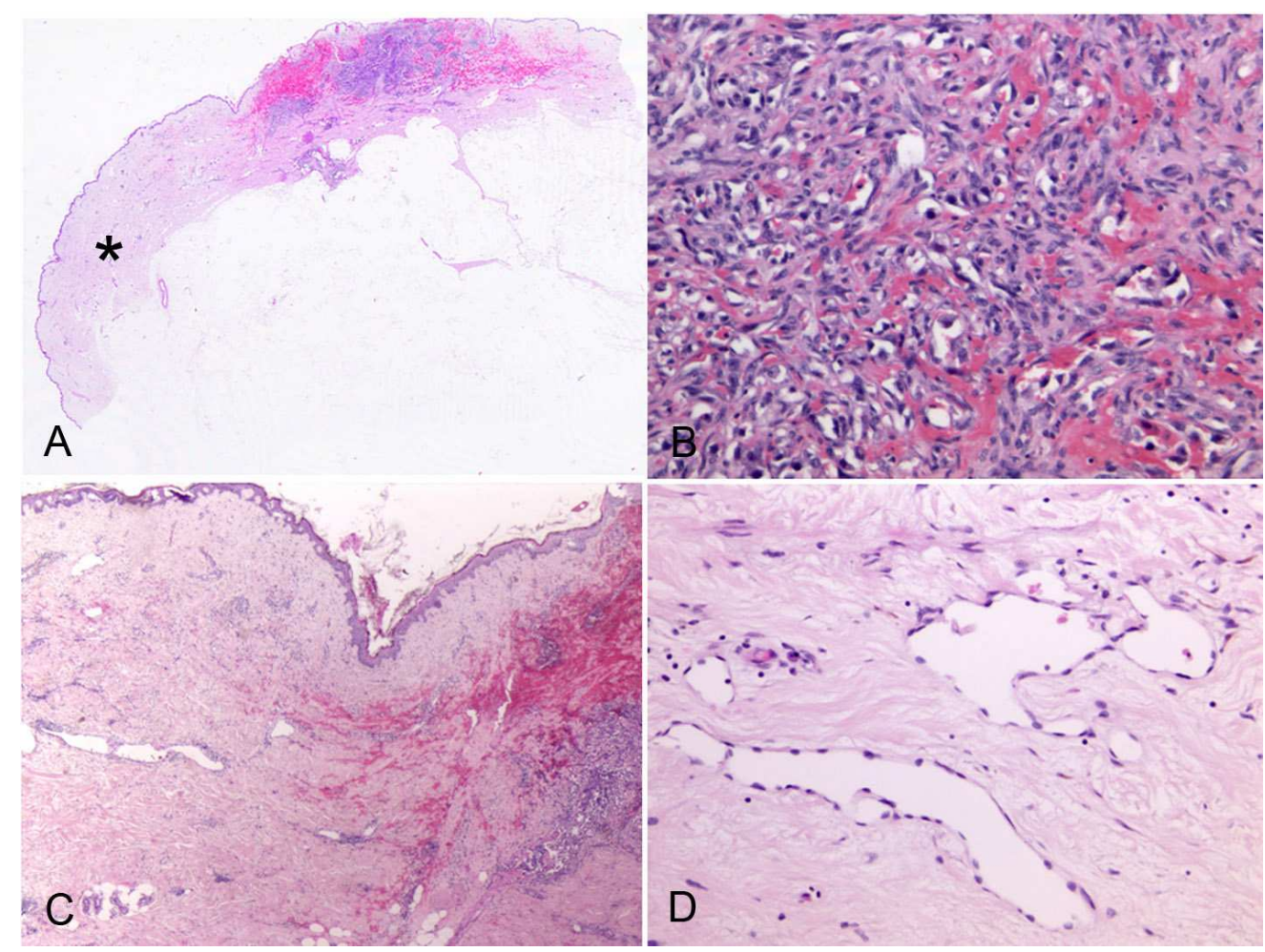

$119 \times 90 \mathrm{~mm}(300 \times 300$ DPI $)$ 


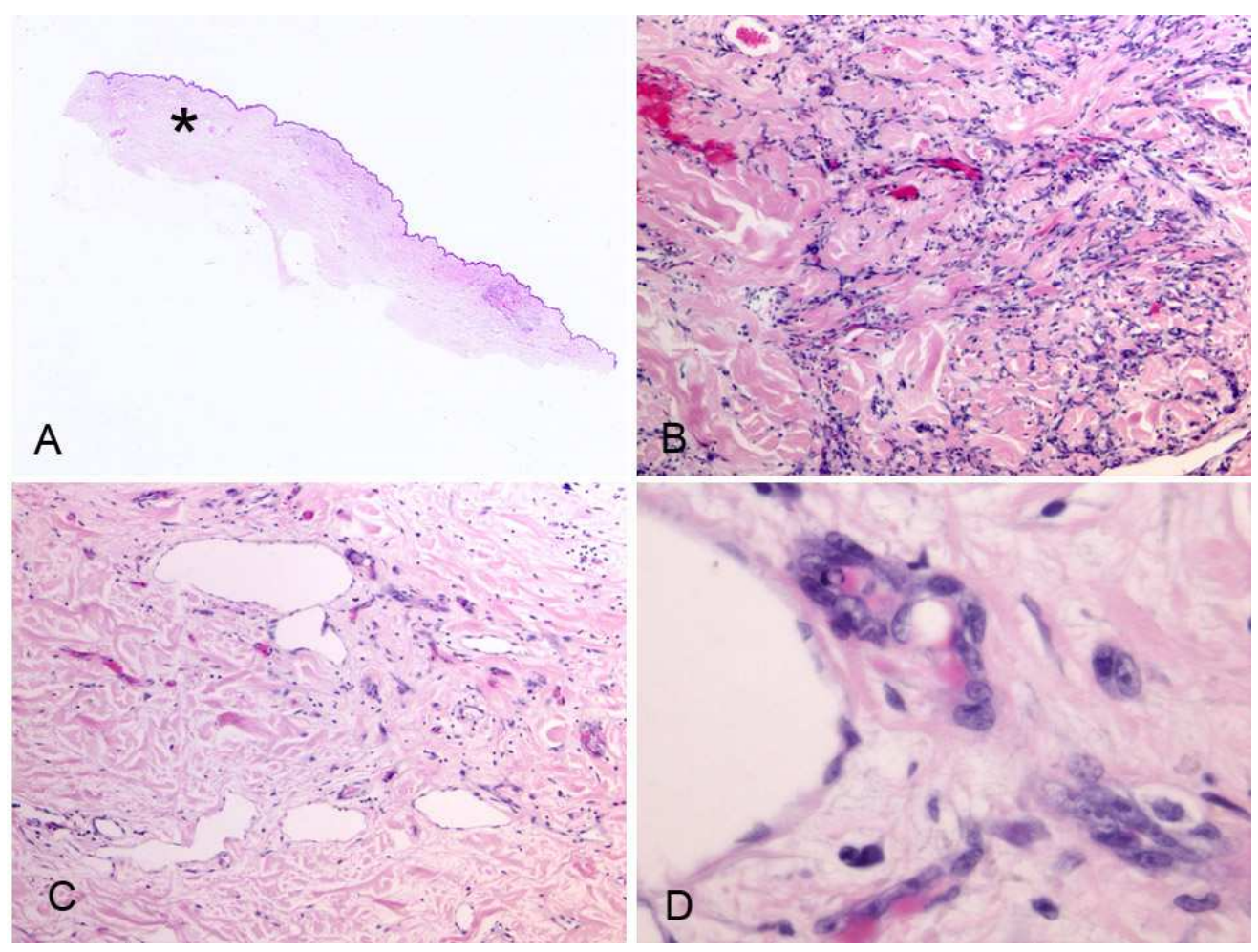

$252 \times 188 \mathrm{~mm}(96 \times 96$ DPI $)$ 

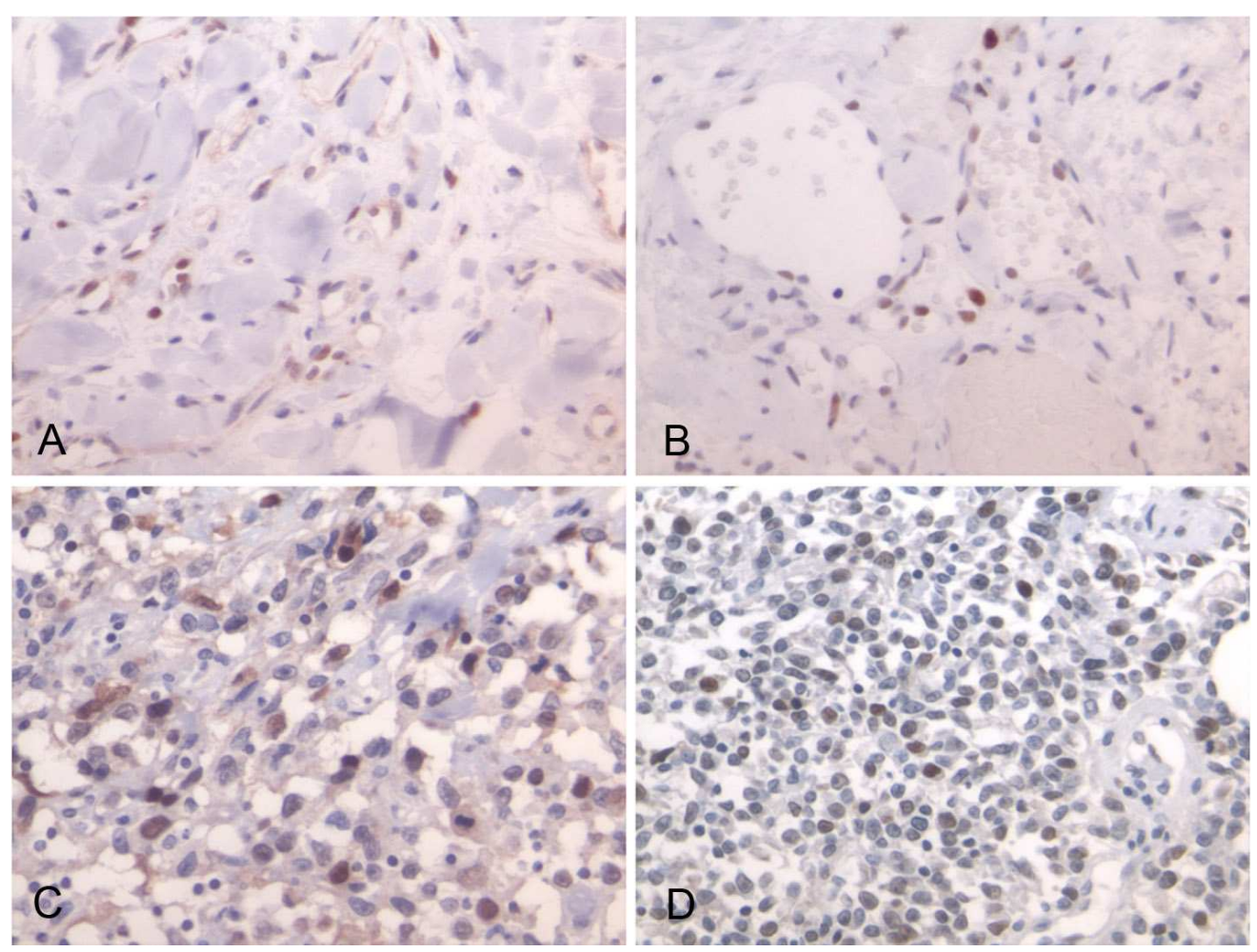

$119 \times 90 \mathrm{~mm}(300 \times 300$ DPI $)$ 


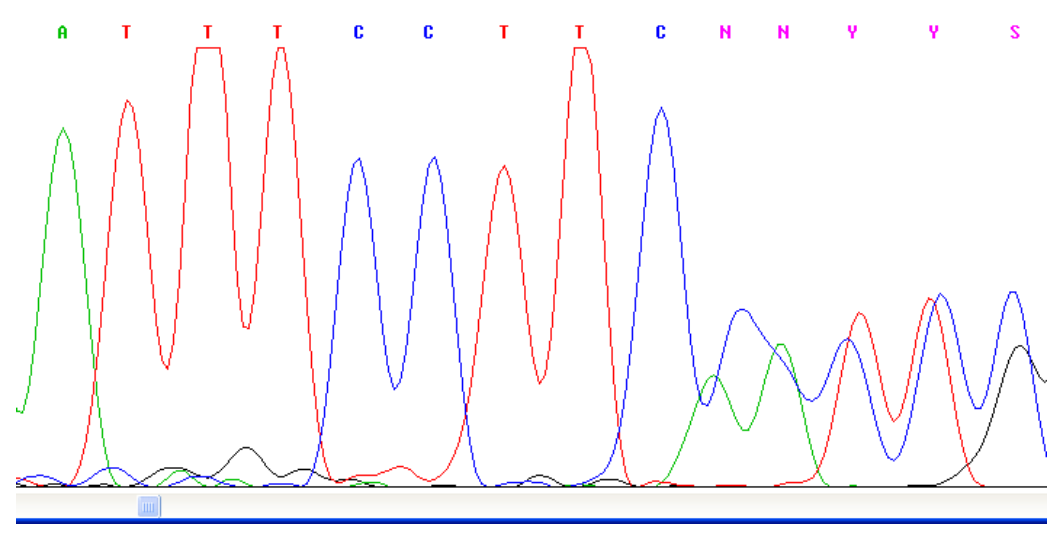

Figure 8 